University of Rhode Island

DigitalCommons@URI

Open Access Master's Theses

1972

\title{
The Effects of Auditory and Shock Stimulation Experienced in Infancy on Subsequent Emotionality and Learning in the Rate
}

Arnold Charles Small

University of Rhode Island

Follow this and additional works at: https://digitalcommons.uri.edu/theses

\section{Recommended Citation}

Small, Arnold Charles, "The Effects of Auditory and Shock Stimulation Experienced in Infancy on Subsequent Emotionality and Learning in the Rate" (1972). Open Access Master's Theses. Paper 1720. https://digitalcommons.uri.edu/theses/1720

This Thesis is brought to you for free and open access by DigitalCommons@URI. It has been accepted for inclusion in Open Access Master's Theses by an authorized administrator of DigitalCommons@URI. For more information, please contact digitalcommons-group@uri.edu. 
THE EFFECTS OF AUDITORY AND SHOCK STIMULATION EXPERIENCED IN INFANCY ON SUBSEQUENT EMOTIONALITY AND LEARNING IN THE RAT

BY

ARNOLD CHARLES SMALL

A THESIS SUBMITTED IN PARTIAL FULFILLMENT OF THE REQUIREMENTS FOR THE DEGREE OF

MASTER OF ARTS

IN

PSYCHOLOGY

UNIVERSITY OF RHODE ISLAND

1972 


\section{ABSTRACT}

In this study, 79 young rats were exposed to different types of infantile stimulation in order to determine the effects of stimulation of different sensory modalities on emotionality and learning. Between the eleventh and twentieth days of life, the subjects received either a 25 volt A.C. shock, 75 decibels of white noise (aversive auditory stimulation), or 45 decibels of white noise (nonaversive auditory stimulation). One group was handled (handled control) and another group was left alone (nonhandled control). The hypothesis tested was that the different types of stimulation would lead to a reduction of emotionality and an increase in learning ability. The nonhandled control group suffered from an extremely high moxtality rate and was excluded from most of the statistical analyses.

There were no differences between the groups in learning ability. The results were mixed in regard to adult emotionality. There were no significant differences between the experimental groups; however, on some measures, there were significant differences between one or more of the experimental groups and the handled control. Where significant differences were found to exist, the shock 
group was always found to differ from the handled control group, with the shock group bejng less emotional than the handled control group in these instances. Although there were no significant differences between the shock and the other experimental groups on any of the dependent measures, the shock group always had the best performance. 


\section{ACKNOWLEDGEMENTS}

The writer wishes to thank the members of his Thesis Committee: Dr. James Proshaska, Chairman; Dr. Henry Biller; and Dr. Nelson Smith. Their time, effort, patience and guidance certainly made this endeavor a meaningful and rewarding one.

Deepest appreciation is extended to Mrs. Mildred Hoffman, who so willingly served as co-experimenter, and to her husband, Mr. William Hoffman, who so patiently endured her long hours in the laboratory.

Finally, to my wife Natalie, who added love, support, and encouragement throughout the study, my most sincere thanks and love. 
TABLE OF CONTENTS

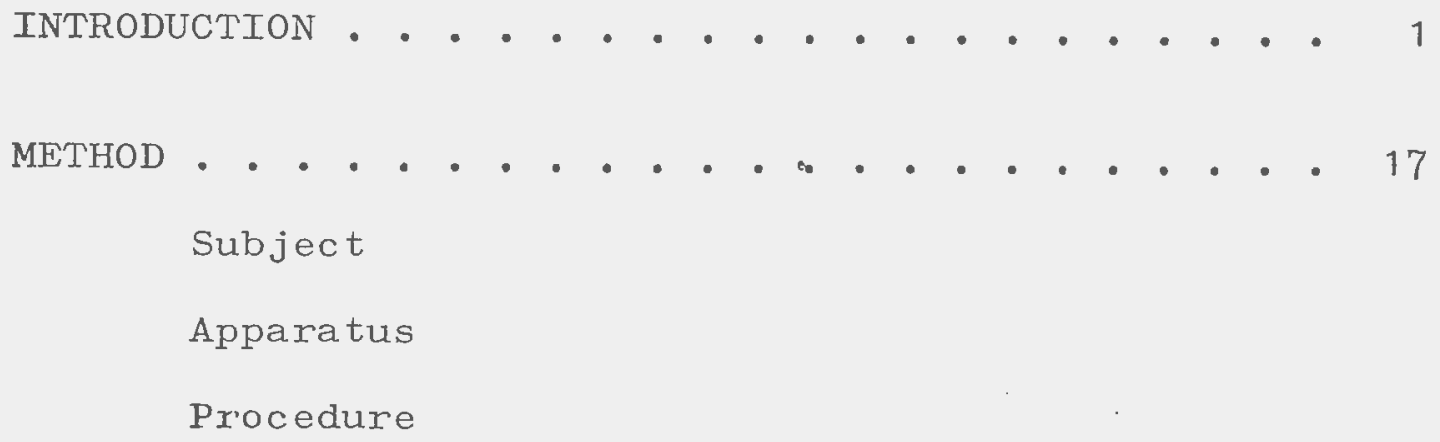




\section{LIST OF TABLES}

Table.

Page

1. Summary of Important Studies

$13-14$

2. Mean and Standard Deviation of Number of Squares Entered in the Open-Field . . . . . 23

3. Mean (Seconds) and Standard Deviation of Time to Energe from the Start Box... . . 26

4. Variances, $F$ Values, and $H$ Values of Time to Emerge. max. . . . . . . . . . 28

5. Summary of Results of the Multiple Comparison Rank Sum Test Reported in Min Values . . . 30

6. Mean and Standard Deviation of Errors in the Hebb-Williams Maze . . . . . . . 34 


\section{LIST OF FIGURES}

Figure

Page

1. The average number of squares entered by each group on the three trials . . . . . . 24

2. Average time to emerge from the start box by each group on each trial separately and on all three together 


\section{INTRODUCTION}

Hunt (1964) suggested that up until the time of Freud, the importance of early experience as a factor influencing later behavior was considered relatively unimportant. Freud (1905) introduced a change in the emphasis of early experience and hypothesized that the experience of traumatic stimulation in infancy rendered an individual more prone to anxiety in adulthood. This then became the accepted and unquestioned view for a good many years. However, interest again grew, and work in this area was stimulated by Hebb (1949) and Helson (1959).

$\mathrm{Hebb}(1949)$ pointed out that as a young animal comes to encounter a wide range of stimulation during infancy, a variety of receptor inputs may help to innoculate him against fear of the unfamiliar and strange. He speculated that the human infant, encountering a variety of stimulation during infancy, may be expected to facilitate the development of those autonomic processes that are conceived to mediate an organism's capacity to profit from later experience, i.e. enriched experiences early in life lead to permanent brain changes which enhance problem-solving capacity.

Helson (1959) expressed a similar vi.ew in his adaptation. level theory. According to him, any stimuli repeatedly 
encountered tends to lose some of jts special characteristics over time; it gradually becomes typical. More specifically, Helson states:

For every condition or complex of conditions in which a receptor system is stimulated, there is an initial rapid change in activity and sensitivity, if the stimulation is continued at a constant intensity. Conversely, all receptor activities and sensitivities are referable to steady states that are reached if stimulation remains constant. (Helson, 1964, p. 45)

Helson continues and states that important differences exist among the various sense modalities in rates of adaptation.

Research in early experience has taken two lines. First there are the experiments involving stress (e.g., shock, auditory stimulation)。 Second, there are the experiments derived from Hebbian concepts in which the environment of the subject is modified in some way, i.e. made more complex or restricted (King, 1958). Although appearing to be dissimilar in nature, if emotionality is defined as the capacity to profit by experience, then each encounter with a form of stimulation may be seen chiefly as an enrichment of that particular variety of stimulation (Salama and Hunt, 1964), and the two lines of research merge。

The effects of infantile stimulation on emotional reactivity has most often been in the form of painful shock, handling, and gentling. Different operational measures of emotionality, which are widely divergent, have been employed. 
Denenbexg and Morton (1962a) handled rats daily between birth and weaning ( 25 th day of life). In an open field situation, these rats were significantly more active and had a significantly lower defecation rate than nonhandled controls. Similar results were obtained when rats were. shocked three minutes daily between days 11-20 (Denenberg and Smith, 1963). Levine (1957, 1958) handled shocked, or did not disturb rats between birth and weaning. At 65 days of age, rats were deprived of water for 18 hours and then placed in individual cages. In both experiments, the handled and shocked rats consumed significantly more water than nonhandled controls. Similarly, Lindholm (1962) found that rats shocked in infancy initiated drinking significantly faster and also drank significantly more water. Hunt and otis (1963) exposed rats to a variety of stimulus conditions. They found that the stimulated groups emerged from their cage into a runway significantly faster than did nonhandled controls. As can be seen, the results are highly consistent and ". . leads to the conclusion that stimulation administered between birth and weaning brings about a reduction in 'emotional reactivity' (Denenberg, 1964, p. 338)."

The effects of infantile stimulation on learning also point to the conclusion that infantile experiences are associated with increases in later ability to learn. The criterion of number of trials required to develop a response that avoids painful stimulation as measure of 
ability to learn, has been commonly used (Denenberg, 1964). The studies which support the above stated generalization a11 involved shock avoidance learning as the dependent variable and contains a noxious or stressful component. The relationship between infantile stimulation and learning, when the emotional component has been reduced, lead to findings that are not as clear-cut.

Hebb (1947) blinded a group of rats in infancy and another at maturity. A third group was reared in the usual laboratory cages while a fourth group was reared as pets in a much wider environment. The groups that had the greater infantile experience led to a higher level of intelligence, as measured by the Hebb-Williams maze. Forgays and Forgays (1952), Denenberg, Woodcock, and Rosenberg (1968), and Brown (1966) found essentially the same results using the Hebb-Williams maze.

Although the beneficial effects of infantile experience on learning have been replicated numerous times, opposite results do appear. Denenberg and Morton (1962) in a series of experiments concluded that the preweaning procedures of handling, larger cages, and greater opportunity for visual experience did not affect problem-solving behavior as measured by the Hebb-Williams maze. Handling in the above study consisted of the rat being removed from the cage and being placed in cans partially filled with shavings for three mimutes. Schaefer (1963) handled a group of rats. When tested in the Hebb-Williams maze, 
there was no difference between the handled group and the nonmanipulated controls. Wong (1966) found the same results using a $\mathrm{T}$ maze. Woods, Ruckelshaus, and Bowling (1960) found that free and restricted animals do not differ in their ability to learn a discrimination in an apparatus where the opportunity to explore was minimized. However, when tested in the Hebb-Williams maze, where there is a chance to explore, the restricted groups made more errors than the free groups. The close relation between performance and exploration measures led them to conclude that the differences were not due to intelligence, but to differences in exploratory behavior. A later study by Woods, Fiske, and Ruckelshaus (1961) confirmed these results. One of the most comprehensive studies was carried out by Salama and Hunt $(1964)$. One group of rats was placed on a grid daily between days 11-20 and were shocked for three minutes; the shock was repeatedly increased from about 60 microamps upward so that the pups squealed continuously. The handled group received the same treatment, except they were not given the shock. A third group, the gentled group, was carried in the palm of the hand and stroked at the rate of fifty strokes per minute for three minutes.

Salama and Hunt proposed that the theories of Hebb and Helson might operate independently. According to Hebb, the effects of infantile stimulation should be similar, since if the encounters with stimuli are made to occur at 
a point early in the life of the infant organism in which he has not had the opportunity to have developed autonomous central processes mediating the interpretation of such inputs, the effects of development, emotionality, and learning should be similar. Helson proposed that encounters with painful stimuli should reduce the aversiveness of later encounters with such stimuli. However, the effects of various forms of stimulation should differ. Gentling, if it is a pleasurable experience for infant rats (Ader, 1968, among others, assumes the position that any type of handling is aversive) might be expected to increase rather than decrease the aversiveness of later encounters with painful stimulation. Using several different measures of emotionality, they found that shock, handling, and gentling had common effects. They concluded that it is stimulation per se that counts in infancy, thereby supporting Levine who came to the same conclusion five years earlier. Since the authors found that shock stimulation differed from handling and gentling in a fairly consistent manner on other measures, they felt that Hebb's theory was not totally correct. Some of the differences are mentioned later in the paper.

Levine (1959) studied the effects of infantile stimulation on emotionality in the absence of handing. One group of rats was placed on an Eberlach Lab Shaker and was shaken for two minutes at 180 oscillations per minute. Another group was placed on the shaker but was not shaken. 
Another group received the same treatment except that the mother was removed from the litter. Handling was avoided by placing the whole cage on the shaker. Levine found that the nonstimulated rats that were left unmolested in their cages, exhibited a significantly greater amount of defecation in a novel situation than the stimulated groups. One the basis of these results, Levine feels that handling per se is not the critical factor which leads to reduced emotionality and accelerated development, and that there are no differences in behavior between different modes of stimulation.

Studies involving shock, handling, or gentling all involve tactile stimulation. Studies comparing the effects of tactile and auditory stimulation or auditory stimulation alone in infancy on emotionality and learning are few.

Spence and Maher (1962a) compared handling and intense auditory stimulation (trauma). The cage containing the litter of subjects with the mother removed was taken to the experimental room and placed in a metal tub with a metal. cover. They were given auditory stimulation which was produced by a buzzer-doorbel1 combination and was given aperiodically over a two-minute span. The handled group was gently removed by hand to a series of boxes and then back to the living cages, for six handling actions in all. The treated control group was taken to the experimental room in their cages, but received no treatment. Animals 
that were left unmolested in their.living cages exhibited greater emotional responsiveness as judged by water consumption, when placed in a novel and in an anxiety-provoking situation, than the experimental groups. The experimental groups did not differ from the treated control group, and also did not differ from each other.

Hall and Whiteman (1951) found results just the opposite. Infant mice were stimulated with a loud, high frequency bell for four two-minute periods (between days 4-7 of life). Mice that received the stimulation defecated and urinated significantly more than nonmanipulated controls in an open-field test. Repeated testing seventy days later in the open-field yielded no significant differences between the groups. A "stovepipe test" was also carried out. This test yielded two measures: time in the start box and time in the stovepipe. There were no significant differences between the groups on these measures. However, Hall and whiteman point out that although there were significant differences only on the first open-field testing, the differences that existed on the other measures were consistent with the findings on the first openfield test, $i . e$. the experimental group showed a greater amount of emotional instability.

The results are also equivocal when the comparison of stimulation across different modalities on learning are studied. Spence and Maher (1962b) used the same procedure as in their aforementioned study. The two groups used, trauma (auditory stimulation) and handling groups, were further differentiated according to their age at time of 
treatment: days 1-20 (early) and days 61-80 (1ate). Three control groups were also used: Early and late controls which were subjected to the same procedures as the trauma and handling groups, except that they were not given any special treatment in the experimental room, and untreated controls, which were left unmolested in their cages. The subjects were required to run down a straight alley to a food reward rather than to escape noxious or anxiety-provoking stimuli. The authors felt that learning tasks that have been usually employed in studies of early experience (complex mazes, instrumental or avoidance learning) appear to be particularly favorable in eliciting overt emotional responses which interfere with efficient performance. Spence and Maher felt that the learning task utilized in the present study would elicit few emotional responses. The results of the study were that the running speeds of subjects in the early and late control groups were significantly slower than those of the subjects in the handling and trauma groups, and that the late groups were slower than the early. However, the untreated controls occupied an intermediate position, which was not expected. The authors concluded that the results were equivocal and suggested that the obtained difference was a function of emotional rather thas learning factors. Griffiths and Stringer (1952), among other conditions of stimulation, subjected one group of rats to an intense auditory stimulus once daily during the first nine 
days of 1ife, and twice daily from the 10th through 21 st days (the auditory stimulation was provided by a 110-volt electric bell). Another group of rats was subjected to shock for three minutes on the same days and in the same manner as the group receiving auditory stimulation, except that the shock was progressively increased. Tested in an open-field for emotionality and in the Warner-Warden maze and modified Lashley discriminątion apparatus for learning ability, there were no significant differences between the experimental and control animals. Griffiths and Stringer state that ". . intense stimulation experienced during infancy does not measurably effect adult life (p. 304)." Griffiths and Stringer found no differences between the experimental groups and the experimental and control groups. The results are interesting in relation to Salama and Hunt's suggestion (1964). Although they found that shocking, handling, and gentling have much in common and that what they have in common is that which derives from encountering a variety in stirulation, they did find that shock stimulation differs from handling and gentling in a fairly consistent manner in some of its effects. For example, gentled rats were heavier while shocked rats were lighter than controls at weaning, and the gentled group averaged significantly less time in moving from the start box to the goal box in their first encounter in the $T$ maze than did shocked animals. They suggested that the degree of differentiation of effects would increase with the 
degree of difference along the pain-pleasure continuum. That the experimental groups did not differ is not surprising in relation to Salama and Hunt's suggestion (a1though it appears that the auditory and shock stimulation were not equal in aversiveness), but the fact that they did not differ from the control groups is surprising.

The results become even more perplexing when compared to the work of Campbell and Bloom (1965). By use of a spatial technique, they were able to assess relative aversiveness of sound (white noise) and shock in a rat. The validity of the method in obtaining relative aversiveness has been further supported by Masterson (1966). The purpose of Campbell and Bloom's work was to determine if equally aversive stimuli are equally motivating, i.e. if they elicit equal performance in specific learning situations. They compared the key pressing performance motivated by escape from equally aversive levels of shock and noise. Noise motivated performance decreased over each training session, in contrast to shock motivated behavior which remained relatively constant. They offered as possible explanations that the rats may be adapting to the sound stimuli or becoming more sensitive to electric shock. However, they add that adaptation to auditory stimuli is a well-established phenomenon, while there is no evidence indicating that subjects become more sensitive to shock stimuli over time.

In the studies cited above, procedural differences abound. Very little uniformity is found in important vari- 
ables such as the intensity and type of stimulation, age at which treatment is instituted, duration of treatment, and age in which adult testing begins or takes place. Studies comparing the effects of infantile stimulation across sensory modalities are scarce and poorly controlled. Whereas the effects of infantile stimulation consisting of shock, handling or gentling, on learning and emotionality offer a few generalizations, the studies comparing auditory and tactile stimulation offer no such generalizations. The little uniformity between the studies and conflicting results can be seen in Table 1 .

The purpose of the present study was twofold. First, an attempt was made to determine whether the conclusion by Levine, and Salama and Hunt that it is stimulation per se that matters in regard to emotionality ard learning is valid. If that statement is valid, then the effects of equally aversive auditory and shock (tactile) stimuli, and the effects of nonaversive auditory stimuli should all be similar. Second, an attempt was macle to determine whether Helson's or Hebb's hypothesis was more efficient in regard to emotionality and learning. According to Hebb, any form of stimulation administered before the development of those autonomic processes that are conceived to mediate an organisu's capacity to profit from later experience, will have the same effects. Thus, there should be no difference between the effects of equally aversive auditory and tactile stimuli, aild the effects of nonaversive auditory 
Summary of Important Studies

\begin{tabular}{|c|c|c|c|c|c|c|c|}
\hline Study & $\begin{array}{c}\text { Type } \\
\text { of } \\
\text { Stimulation } \\
\end{array}$ & $\begin{array}{c}\text { Level } \\
\text { of } \\
\text { Stimulation } \\
\end{array}$ & Species & $\begin{array}{c}\text { Days } \\
\text { of } \\
\text { Treatment } \\
\end{array}$ & $\begin{array}{l}\text { Age } \\
\text { Weaned } \\
\end{array}$ & $\begin{array}{c}\text { Type } \\
\text { of } \\
\text { Measures } \\
\end{array}$ & Results \\
\hline $\begin{array}{l}\text { Denenberg } \\
\text { \& Morton } \\
(1962 a)\end{array}$ & $\begin{array}{l}\text { handling } \\
\text { control }\end{array}$ & $\begin{array}{l}\text { placed in cans } \\
\text { for } 3 \text { min. }\end{array}$ & $\begin{array}{l}\text { Purdue- } \\
\text { Wistar } \\
\text { rats }\end{array}$ & $1-24$ & 25 & $\begin{array}{l}\text { activity, } \\
\text { defecation } \\
\text { in open- } \\
\text { field }\end{array}$ & $\begin{array}{l}\text { handled rats more } \\
\text { active and had } \\
\text { lower defecation } \\
\text { rate than control }\end{array}$ \\
\hline $\begin{array}{l}\text { Denenberg } \\
\text { \& Smith } \\
(1963)\end{array}$ & $\begin{array}{l}\text { shock } \\
\text { handling } \\
\text { control }\end{array}$ & $\begin{array}{l}0.25 \text { ma. for } 3 \\
\text { min. ( } 2.25 \text {-megohm } \\
\text { resistor) } \\
\text { placed on grid } \\
\text { for } 3 \text { min. }\end{array}$ & $\begin{array}{l}\text { Purdue- } \\
\text { Wistar } \\
\text { rats }\end{array}$ & $11-20$ & 25 & $\begin{array}{l}\text { no. of } \\
\text { squares en- } \\
\text { tered and } \\
\text { defecation } \\
\text { in open- } \\
\text { field }\end{array}$ & $\begin{array}{l}\text { controls least ac- } \\
\text { tive and had highest } \\
\text { amount of defecation } \\
\text { no differences be- } \\
\text { tween two experimen- } \\
\text { tal groups }\end{array}$ \\
\hline $\begin{array}{l}\text { Levine } \\
(1958)\end{array}$ & $\begin{array}{l}\text { shock } \\
\text { handling } \\
\text { control }\end{array}$ & $\begin{array}{l}\text { 110v. A.C., } \\
\text { limited by resis- } \\
\text { tor of } 78,000 \\
\text { ohms; } 1 \text { sec. in- } \\
\text { tervals, } 1 \text { sec. } \\
\text { in duration for } \\
3 \text { min. } \\
\text { placed on grid. } \\
\text { for } 3 \text { min. }\end{array}$ & $\begin{array}{l}\text { Long- } \\
\text { Evans } \\
\text { hooded } \\
\text { rats }\end{array}$ & $1-20$ & 21 & $\begin{array}{l}\text { water } \\
\text { consumption }\end{array}$ & $\begin{array}{l}\text { controls consumed } \\
\text { significantly less } \\
\text { water than } 2 \text { experi- } \\
\text { mental groups; han- } \\
\text { dled group interme- } \\
\text { diate in amount of } \\
\text { water consumption }\end{array}$ \\
\hline
\end{tabular}


TABLE 1 (Continued)

Summary of Important Studies

\begin{tabular}{|c|c|c|c|c|c|c|}
\hline Study & $\begin{array}{c}\text { Level } \\
\text { of } \\
\text { Stimulation }\end{array}$ & Species & $\begin{array}{c}\text { Days } \\
\text { of } \\
\text { Treatment }\end{array}$ & $\begin{array}{c}\text { Age } \\
\text { Weaned }\end{array}$ & $\begin{array}{c}\text { Type } \\
\text { of } \\
\text { Measures }\end{array}$ & Results \\
\hline $\begin{array}{l}\text { Hebb } \\
(1947) .\end{array}$ & $\begin{array}{l}\text { enriched free } \\
\text { environment } \\
\text { usual lab cages } \\
\text { blinded in infancy } \\
\text { blinded at maturity }\end{array}$ & rats & - unspec & ified - & $\begin{array}{l}\text { Error } \\
\text { scores in } \\
\text { Hebb-Will. } \\
\text { maze }\end{array}$ & $\begin{array}{l}\text { greater infantile } \\
\text { experience (en- } \\
\text { riched free environ } \\
\text { ment) led to a } \\
\text { higher level of in- } \\
\text { telligence at } \\
\text { maturity }\end{array}$ \\
\hline $\begin{array}{l}\text { Denenberg } \\
\text { \& Morton } \\
(1962 b)\end{array}$ & $\begin{array}{l}\text { *handling placed in cans } \\
\text { * for } 3 \text { min. } \\
\text { *ontrol } \\
\text { then placed into } \\
\text { neutral, restricted, } \\
\text { or enriched environments }\end{array}$ & $\begin{array}{l}\text { Purdue- } \\
\text { Wistar } \\
\text { rats }\end{array}$ & $1-24$ & 25 & $\begin{array}{l}\text { error } \\
\text { scores in } \\
\text { Hebb-Will. } \\
\text { maze }\end{array}$ & $\begin{array}{l}\text { handling did not } \\
\text { affect problem- } \\
\text { solving ability as } \\
\text { measured by Hebb- } \\
\text { Williams maze. }\end{array}$ \\
\hline $\begin{array}{l}\text { Salama \& } \\
\text { Hunt } \\
(1964)\end{array}$ & $\begin{array}{l}\text { increased from } 60 \\
\text { microamps; } 3 \text { min. } \\
\text { placed on grid } \\
\text { for } 3 \text { mins. } \\
\text { stroked at rate } \\
50 \text { strokes/min.; } \\
3 \text { min. }\end{array}$ & $\begin{array}{l}\text { Abrams - } \\
\text { Wistar } \\
\text { rats }\end{array}$ & $11-20$ & 28 & $\begin{array}{l}\text { defecation, } \\
\text { urination, } \\
\text { timidity, } \\
\text { activity in } \\
\text { T-maze }\end{array}$ & $\begin{array}{l}\text { different forms of } \\
\text { treatment had simi- } \\
\text { lar effects; stimu- } \\
\text { lation per se that } \\
\text { counts in infancy. }\end{array}$ \\
\hline
\end{tabular}


Summary of Important Studies

\begin{tabular}{|c|c|c|c|c|c|c|c|}
\hline Study & $\begin{array}{c}\text { Type } \\
\text { of } \\
\text { Stimulation }\end{array}$ & $\begin{array}{c}\text { Level } \\
\text { of } \\
\text { Stimulation }\end{array}$ & Species & $\begin{array}{l}\text { Days } \\
\text { of } \\
\text { Treatment }\end{array}$ & $\begin{array}{c}\text { Age } \\
\text { Weaned }\end{array}$ & $\begin{array}{c}\text { Type } \\
\text { of } \\
\text { Measures }\end{array}$ & Results \\
\hline $\begin{array}{l}\text { Levine } \\
(1959)\end{array}$ & $\begin{array}{l}\text { shaken } \\
\text { placed on ap- } \\
\text { paratus in } \\
\text { cage; not shake. } \\
\text { control }\end{array}$ & $\begin{array}{l}2 \text { mins. at } 180 \\
\text { oscillations } \\
\text { per min. }\end{array}$ & $\begin{array}{l}\text { Sprague- } \\
\text { Dawley } \\
\text { rats }\end{array}$ & $1-20$ & $\begin{array}{l}\text { study } \\
\text { ended } \\
\text { weaning }\end{array}$ & defecation & $\begin{array}{l}\text { control rats ex- } \\
\text { hibited signifi- } \\
\text { cantly greater } \\
\text { amount of defeca- } \\
\text { tion; no differ- } \\
\text { ence between stimu- } \\
\text { lated groups }\end{array}$ \\
\hline $\begin{array}{l}\text { Spence } \\
\& \text { Maher } \\
(1962 a)\end{array}$ & $\begin{array}{l}\text { handling } \\
\text { auditing } \\
\text { control } \\
\text { untreated } \\
\text { control }\end{array}$ & $\begin{array}{l}6 \text { handling ac- } \\
\text { tions } \\
\text { produced by } \\
\text { buzzer-doorbell } \\
\text { combination; } 2 \\
\text { min.; intermittent } \\
\text { taken in cages to } \\
\text { experimental room; } \\
\text { returned }\end{array}$ & $\begin{array}{l}\text { Wistar } \\
\text { rats }\end{array}$ & $1-20$ & 32 & $\begin{array}{l}\text { water } \\
\text { consumption }\end{array}$ & $\begin{array}{l}\text { UC rats consumed } \\
\text { significantly less } \\
\text { water than experi- } \\
\text { mental groups; no } \\
\text { difference between } \\
\text { stimulated groups } \\
\text { and control }\end{array}$ \\
\hline $\begin{array}{l}\text { Hall \& } \\
\text { Whiteman } \\
(1951)\end{array}$ & $\begin{array}{l}\text { auditory } \\
\text { control }\end{array}$ & $\begin{array}{l}\text { loud, high fre- } \\
\text { quency bell for } \\
\text { four 2-min. pds. }\end{array}$ & $\begin{array}{l}\text { mice; off- } \\
\text { spring of } \\
\text { C-57 and } \\
\text { dba }\end{array}$ & $4-7$ & -- & $\begin{array}{l}\text { defecation; } \\
\text { urination; } \\
\text { time in start } \\
\text { box and time } \\
\text { in stovepipe }\end{array}$ & $\begin{array}{l}\text { experimental group } \\
\text { defecated and urin- } \\
\text { ated significantly } \\
\text { more than control; } \\
\text { no sig't difference } \\
\text { on stovepipe test }\end{array}$ \\
\hline
\end{tabular}


TABLE 1 (Continued)

Summary of Important Studies

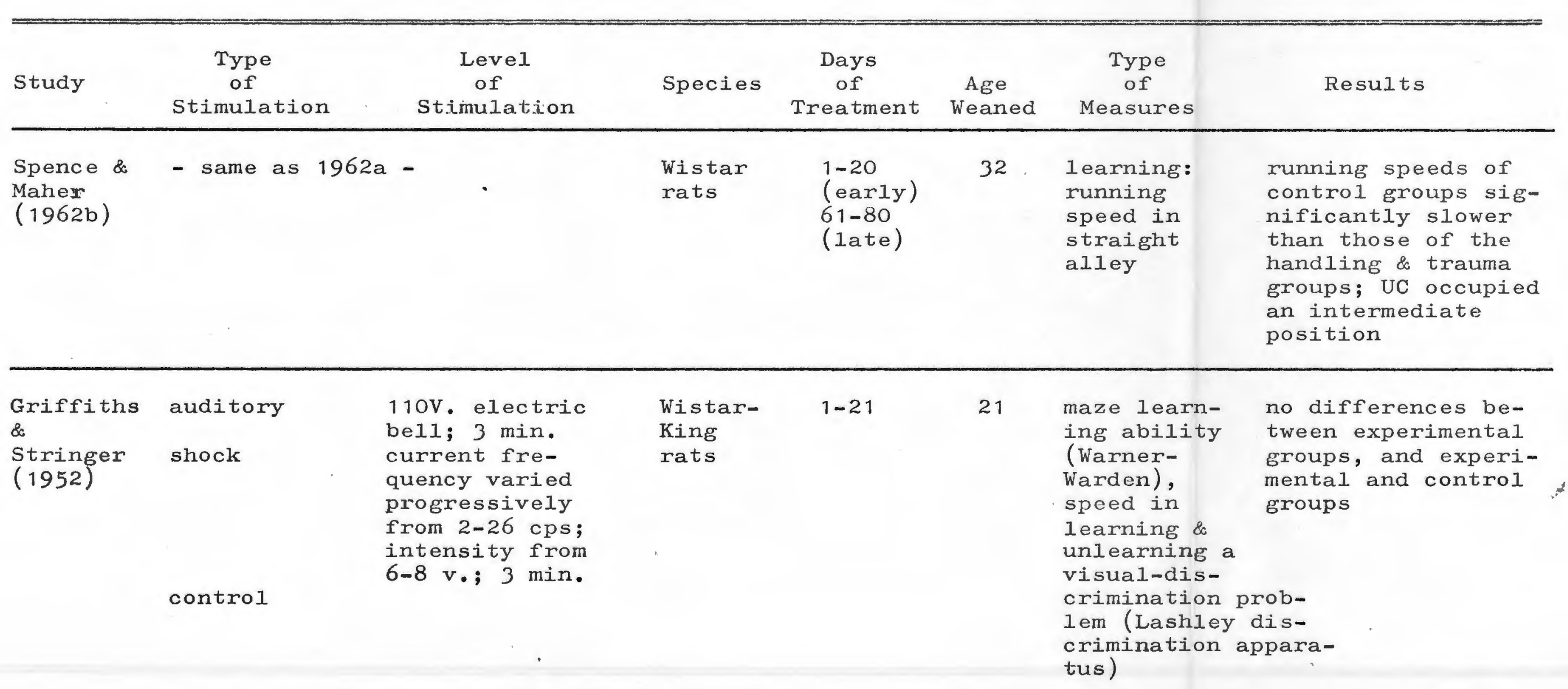


stimuli. According to Helson, there should be a difference in the effects due to the important differences that exist among the various sense modalities in rates of adaptation. The independent variable was the type of treatment or stimulation: shock, aversive auditory ( $\Lambda A)$, nonaversive auditory stimulation (NAA), handled control (HC), and nonhandled control (NHC). The shock and aversive auditory stimulation were equated for ręlative aversiveness for the rat (Campbell and Bloom, 1965). The determination of the nonaversive level of auditory stimulation was based on Campbell's work (1957). One test for emotionality and one for learning were carried out. The dependent variables for the emotionality measures were: (1) total number of squares entered in the open-field situation, (2) time to emerge from the start box into the open-field, and (3) total number of animals that defecated and urinated in the openfield. The total number of errors made in the Hebb-Williams maze served as the dependent variable for the learning measure.

It was expected that the rats that did not receive any stimulation in infancy would be more emotionally reactive and would enter a fewer number of squares in the open-field, would more likely defecate and urinate, and have a lorger latency in emerging from the start box than rats that recieved stimulation in infancy. Also, it was expected that they would commit more errors in the HebbWilliarns maze. 
As mentioned previously, Hebb would postulate that there would be no differences between the experimental groups on the learning and emotionality measures, but that they would differ from the NHC group. Helson would predict that the shock group would be the least emotional and exhibit the best problem-solving behavior, followed by the AA, NAA, HC, and NHC groups respectively. 
METHOD

\section{$\underline{\text { Subjects }}$}

The subjects were 79 newborn albino rats of the Charles River strain born at the URI Comparative Psychology Laboratory. The mothers of these rats were pregnant when purchased from the Charles River Breeding Laboratory. During the administration of the treatments and until three days before testing in the open-field was to begin, food and water were available ad libitum. At this time, the subjects were placed on a deprivation schedule of about $13 \mathrm{gm}$. of Purina Laboratory Chow daily, with water available ad libitum. They were maintained on this schedule until the end of testing. This schedule maintained the subjects at approximately $80 \%$ of their normal body weight. However, since some of the rats appeared not to be hungry during the beginning of the testing period, further adjustment was made in the amount of food given (i.e., less food was given).

\section{Apparatus}

A section 12-in. long of a straight alley runway measuring 5-in. wide, 7-in. high, and 48-in. long was used for the administration of the experimental treatments. This apparatus had aluminum sides, a Plexiglass top, and a 
grid floor made of stainless-steel rods. The level of shock for the group receiving shock stimulation was a $25 \mathrm{v}$. A.C. from a matched impedance source with $150 \mathrm{~K}$ ohms in series with the rat. The shock was scrambled. The shock was aversive as the pups squealedcontinuously when the shock came on. The group receiving aversive auditory stimulation received white noise at a level of 75 decibels produced by a Grason-Stadler white noise generator and emitted from a Quam speaker. The group receiving nonaversive auditory stimulation received white noise at a level of 45 decibels. The levels of stimulation were chosen on the basis of Campbell's (1957) and Campbell and Bloom's (1965) work .

Performance on the Hebb-Williams maze measured the effects of infantile stimulation on learning. This closed field apparatus consisted of a box with an entrance alley and a food compartment at opposite corners of an open-field. Thirty-six 5-in. squares outlined in black on the unpainted plywood floor of the open-field served to define error scores and act as markers for placing the barriers. There were 14 barriers: three 5-in. 1ong, four 10-in. 1ong, three 15-in. long, two 20-in. long, and two 25-in. long, consisting of stock .5 x 4-in. dressed lumber. Depending on their placement in the field, 12 test problems were constructed. The walls were black and made from .5 x 4-in. dressed lumber. 
An open-field was used to measure the effects of infantile stimulation on emotionality. This consisted of the same apparatus as the Hebb-Williams maze, but without the barriers and the food compartment.

\section{Procedure}

The litters were placed in large nest cages. The pups were randomly assigned to one of the three treatment conditions (shock, AA, NAA) or to the handled or nonhandled control group. All subjects remained in their cages except for that period of each treatment day during which they received stimulation.

Al1 pups remained unmolested in their cages from days 1-10. On day 11, the experimental treatments began. The group of rats receiving shock stimulation were placed, individually, in the 12-in. compartment of the runway and received a $25 \mathrm{v}$. A.C. shock for three minutes. They were then returned to the nest cage. The same procedure was used for the other two experimental groups, except one received aversive auditory stimulation consisting of white noise with a sound level of 75 decibels, and the other received nonaversive auditory stimulation consisting of white noise with a sound level of 45 decibels. The handled control group was brought to the experimental room, but did not receive any stimulation and was returned to the nest cage. The nonhandled control group was left unmolested in its cage. The three experimental groups received stimulation from 11-20 days of age. To control for the 
effects of handling, all rats were carried in the palm of the hand.

Al1 subjects were weaned on day 30 and assigned to individual, standard size cages. All rats were left unmolested in their cages until 60 days old. On this day, and on the succeeding 2 days, the effects of infantile stimulation on emotionality were determined by individually placing the rats in the open-field situation. One trial was given on each day. The number of squares entered with al1 four feet in five minutes was recorded, as well as the number of animals that defecated and urinated. In addition, time to emerge from the start box into the openfield was also recorded.

Between days 63 and 77 , the subjects were habituated to the Hebb-Williams maze and received practice problems. At 78 days of age, testing began on the sequence of 1.2 test problems described by Rabinovitch and Rosvold (1951). One test problem per day was given and each rat had eight trials on each problem. The subjects score was the total number of errors made throughout the testing period. 


\section{RESULTS}

\section{Distribution of Animals That Died}

Since the NHC group suffered from a high mortality rate, nine died, the group had a $n$ of six. To obtain a $n$ of twelve for each group, it was necessary to have two sets of pregnant rats at different times. This procedure allowed the rats from the second set to be assigned to the conditions based on the mortality rate of the first set of rats. The final distribution of rats that died was: shock group, 2; AA group, 2; NAA group, 2; HC group, 7; and NHC group, 11. All groups had a $n$ of twelve except for the NAA group, which had a $n$ of thirteen, and the NHC group. One rat in the NAA group was discarded on a random basis before the testing began.

On the basis of a chi-square test, it was found that the number of rats that died was not normally distributed throughout the groups $\left(x^{2}=10.683, p<.05\right)$. To determine where the differences were, subsequent chi-square tests were made taking one group at a time versus another group (Downie and Heath, 1965). Since degrees of freedom was one, and the expected frequencies were less than ten, Yates' correction for continuity (Downie and Heath, 1965) was applied. Also, since the shock and AA groups had the 
same $\mathrm{n}$ and observed frequency, a separate analysis was not performed.

It can be seen in Appendix A that the subsequent chi-square tests indicated that the NAA and NHC groups, and the HC and NHC groups were significantly different from each other, with the NHC having the highest mortality rate in each case. Due to the small $\mathrm{n}$, the NHC group was excluded from all of the remaining statistical analyses.

\section{Number of Squares Entered in the Open-Field}

The average number of squares entered on each of the three trials and the average number of squares entered on all three trials together are summarized in Table 2. It was hypothesized that the rats that did not receive any stimulation in infancy would be more emotionally reactive and would enter a fewer number of squares in the openfield. It was necessary to compare performances on each trial in order to determine, if there were differences on the first or second trials, whether the effects would be consistent over the course of the testing period. One-way analyses of variance indicated that there were no significant differences between the groups on the first and second trials, and on all three trials together. There was a significant difference between the groups on the third trial. Figure 1 presents the data graphically.

Dunnett's t statistic (Winer, 1962) was employed to determine where the differences existed on the third trial. 


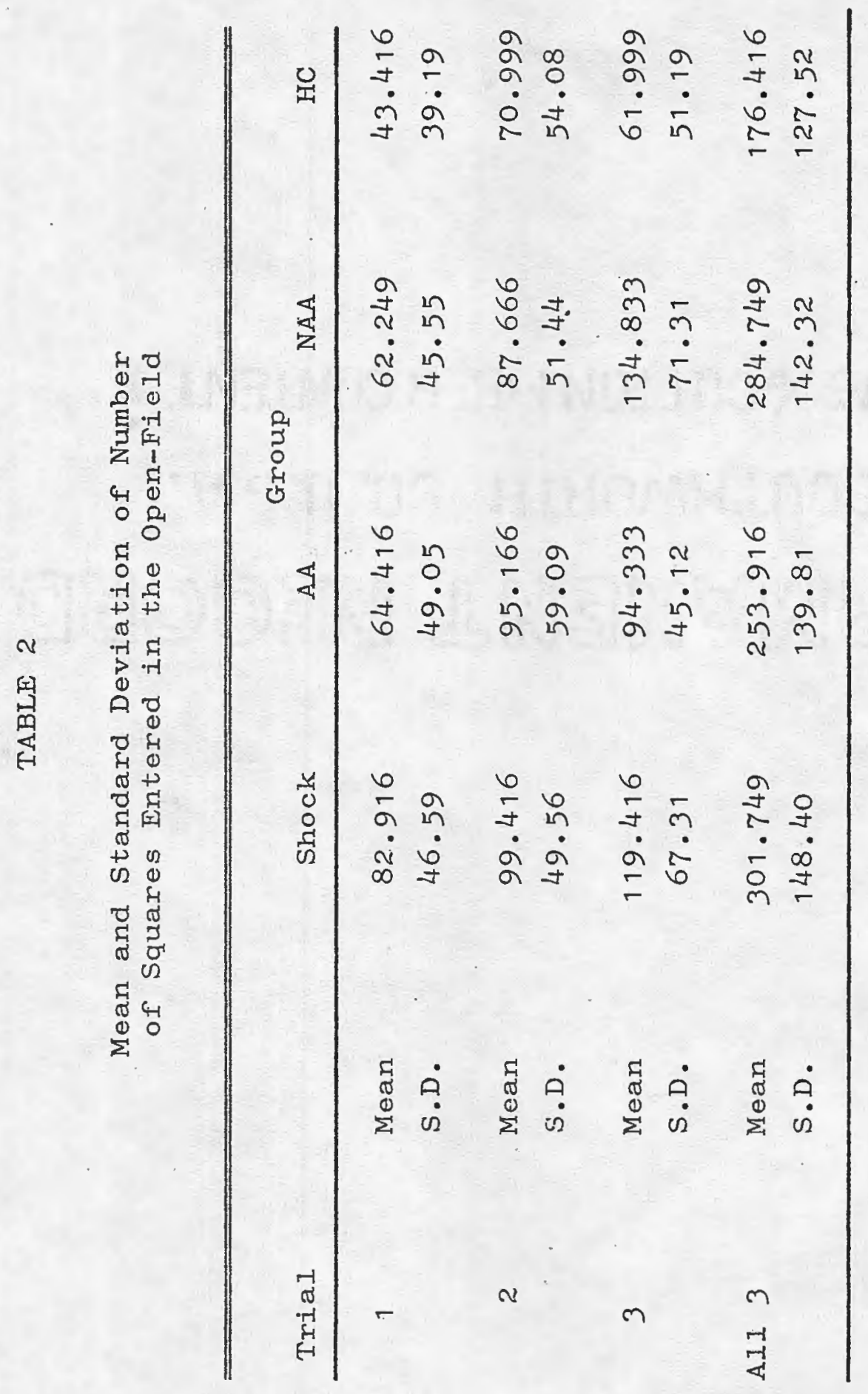




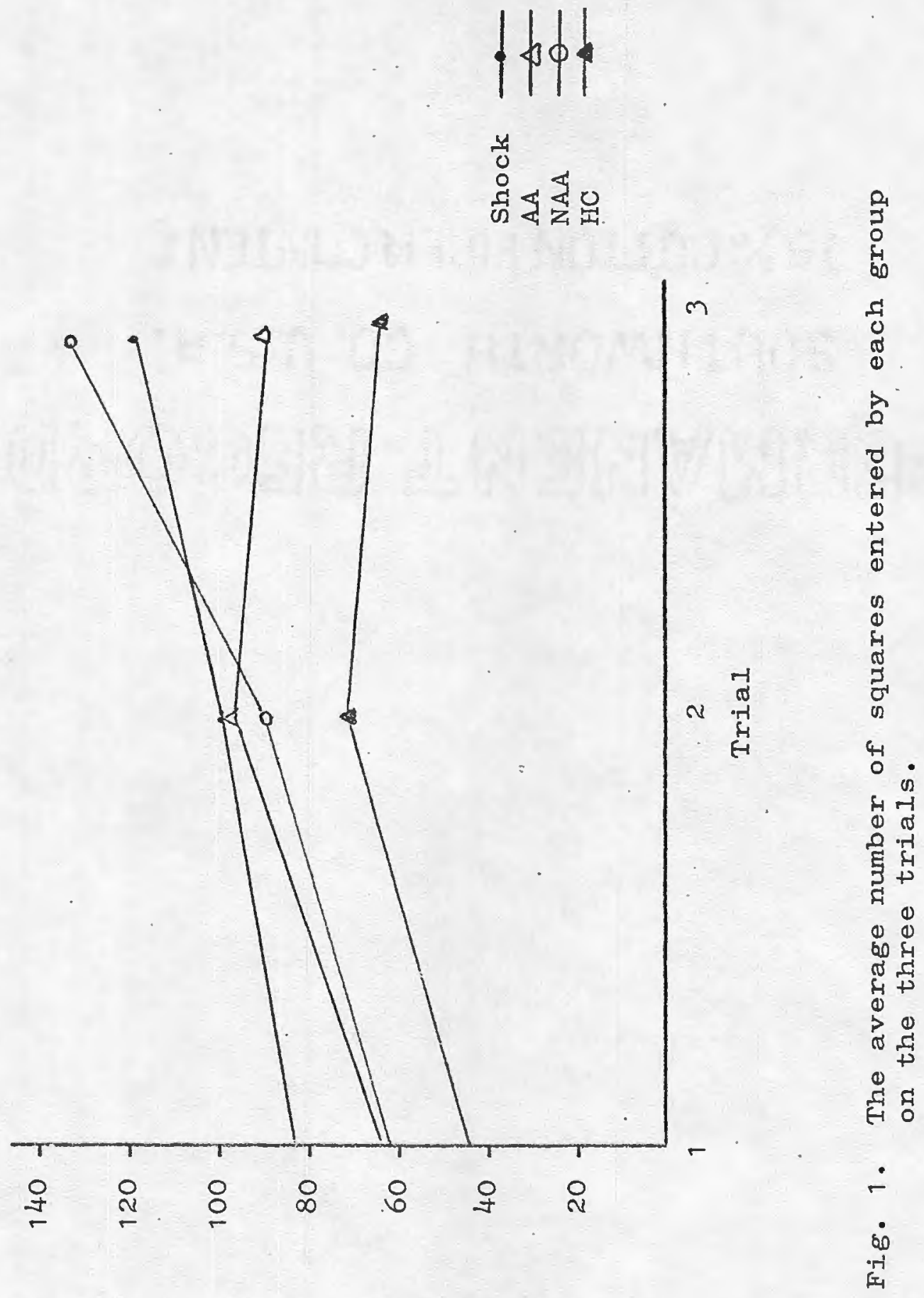

pәxәquझ səxenbs Jo xәqumN UеәN 
This analysis indicated that the shock and the NAA group both entered significantly more squares than the HC group. The AA group was not significantly different from the HC group. To determine whether there were any differences between the experimental groups, a separate analysis of variance without the HC group was run. No differences in the number of squares entered in the open-field were found to exist between the experimental groups. Thus, the only differences found to exist in regard to the number of squares entered in the open-field was between the shock and HC groups, and the NAA and HC groups on the third trial. Both the shock and NAA groups entered significantly more squares than the HC group.

\section{Time to Emerge From the start Box}

Time to emerge from the start box was defined as the amount of time to place all four feet in the open-field. It was expected that those rats that did not receive infantile stimulation would have a longer latency in emerging from the start box than rats that received infantile stimulation. Time to emerge was also compared on a trial by trial basis. Table 3 shows the mean time to emerge from the start box. Figure 2 presents the data graphically. Parametric analyses of variance could not be performed on this set of data because the assumption of homogeneity of variance could not be met. $F_{\max }$ values can be found in Table 4. Instead, Kruskal-Wallis one-way analyses 


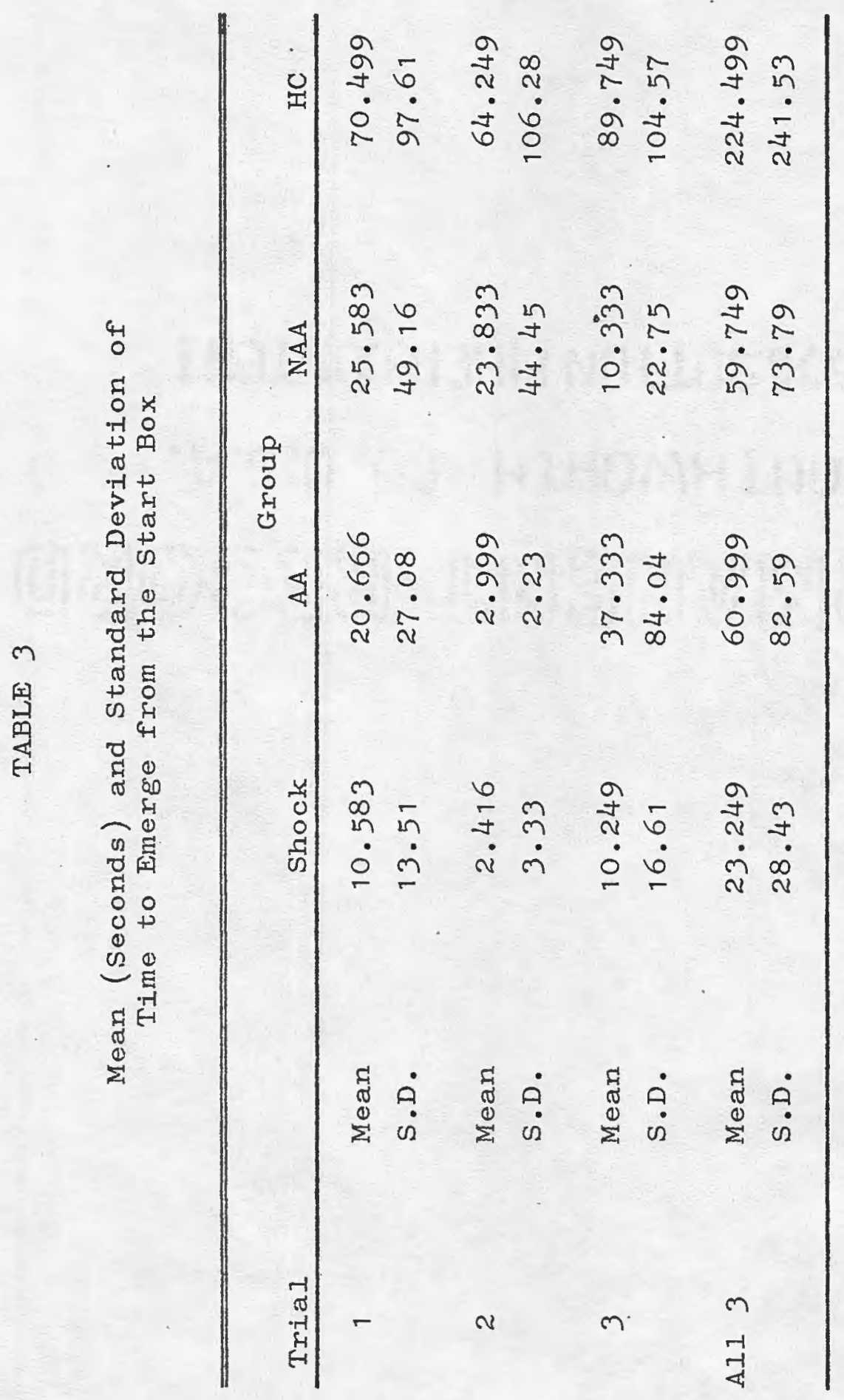




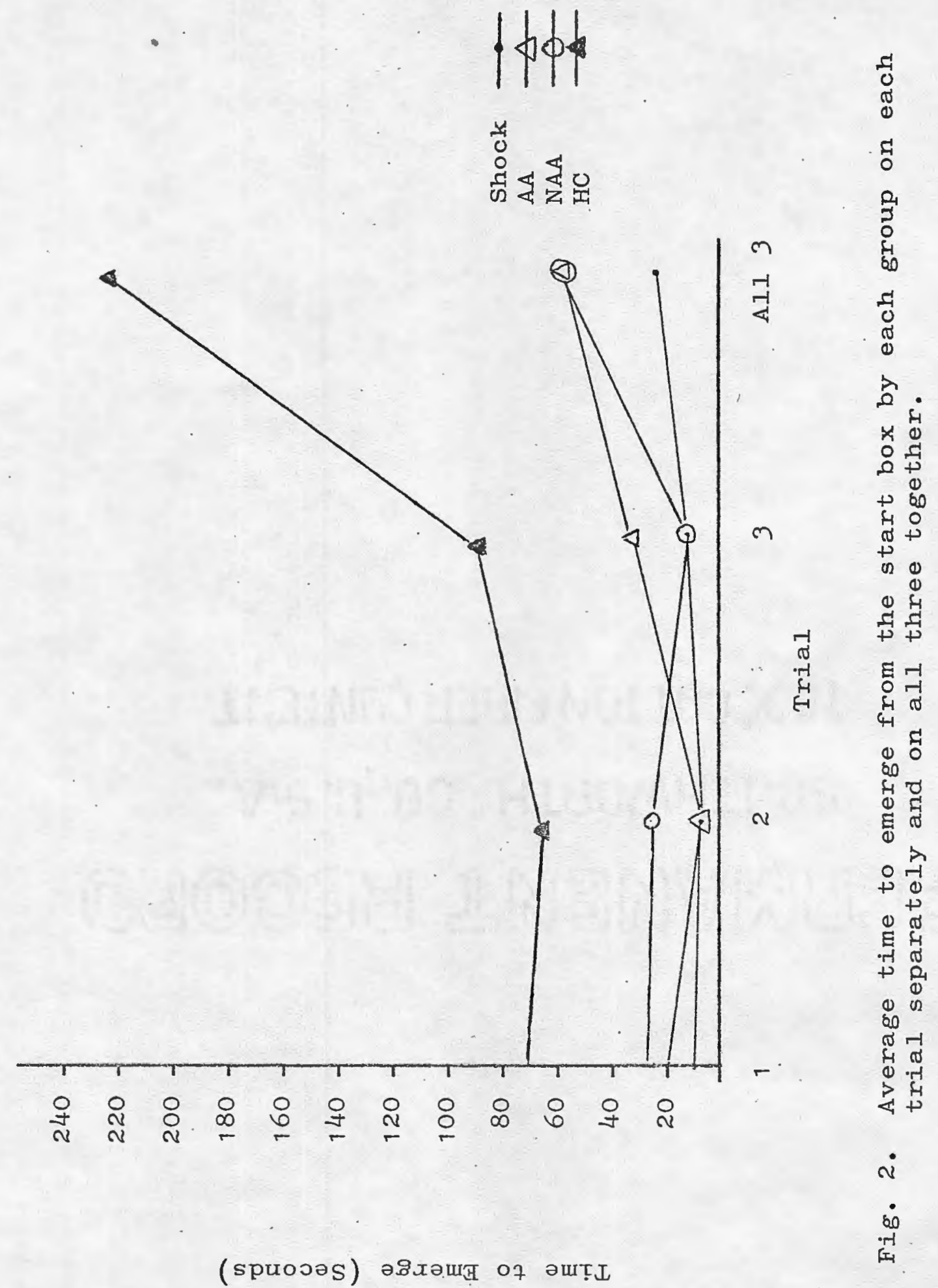




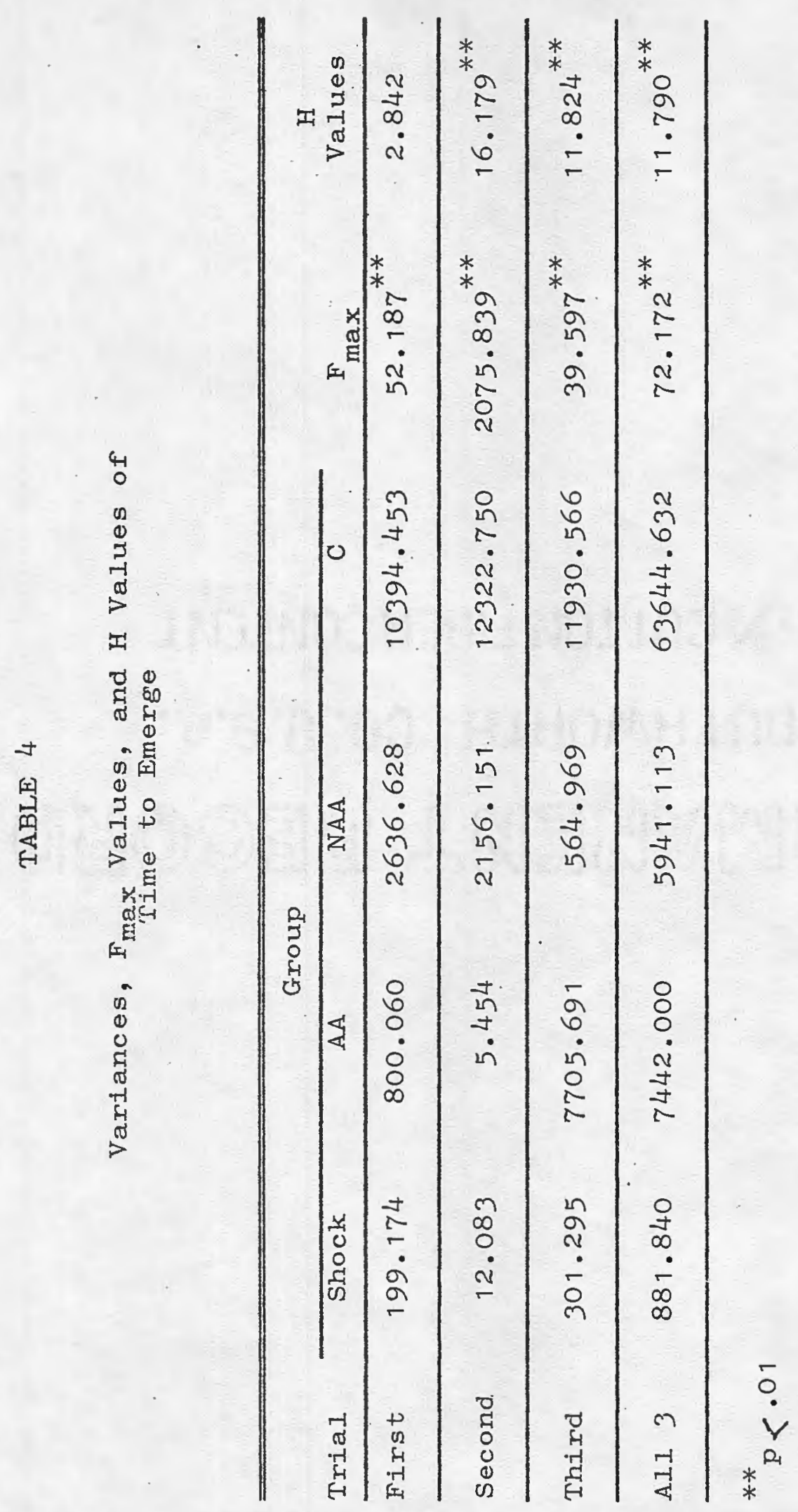


of variance by ranks were performed. The resultant $H$ values, corrected for ties (Siegel, 1956), can also be found summarized in Table 4. It should be noted that there were differences between the groups in time to emerge on all but the first trial.

To determine where the differences lie, a nonparametric analogue of Dunnett's procedure, a multiple comparison rank sum test (Steele, 1959.) was utilized. The results are summarized in Table 5. This analysis showed that the shock and $\mathrm{AA}$ groups had a significantly faster time to emerge than the HC group on the second trial. A KruskalWallis run between the experimental groups found that there were no differences in their time to emerge ( $H=4.279$, p >.05). On the third trial, the shock and NAA groups had significantly faster times than the HC group. Again, a Kruskal-Wallis run between the experimental groups yielded no significant differences $(H=1.893, p>.05)$. On al1 three trials together, the shock group was the only group that was significantly faster than the HC group. A Kruskal-Wallis analysis of variance again indicated no differences between the experimental groups $(H=3.046$, p).05). In summary, (1) there were significant differences between the groups in time to emerge on all trials but the first, (2) there were no differences between the experimental groups on any of the trial.s, and (3) the shock group always displayed a significantly faster time to emerge than 


\section{TABLE 5}

Summary of Results of the Multiple Comparison Rank Sum Test

Reported in Min Values

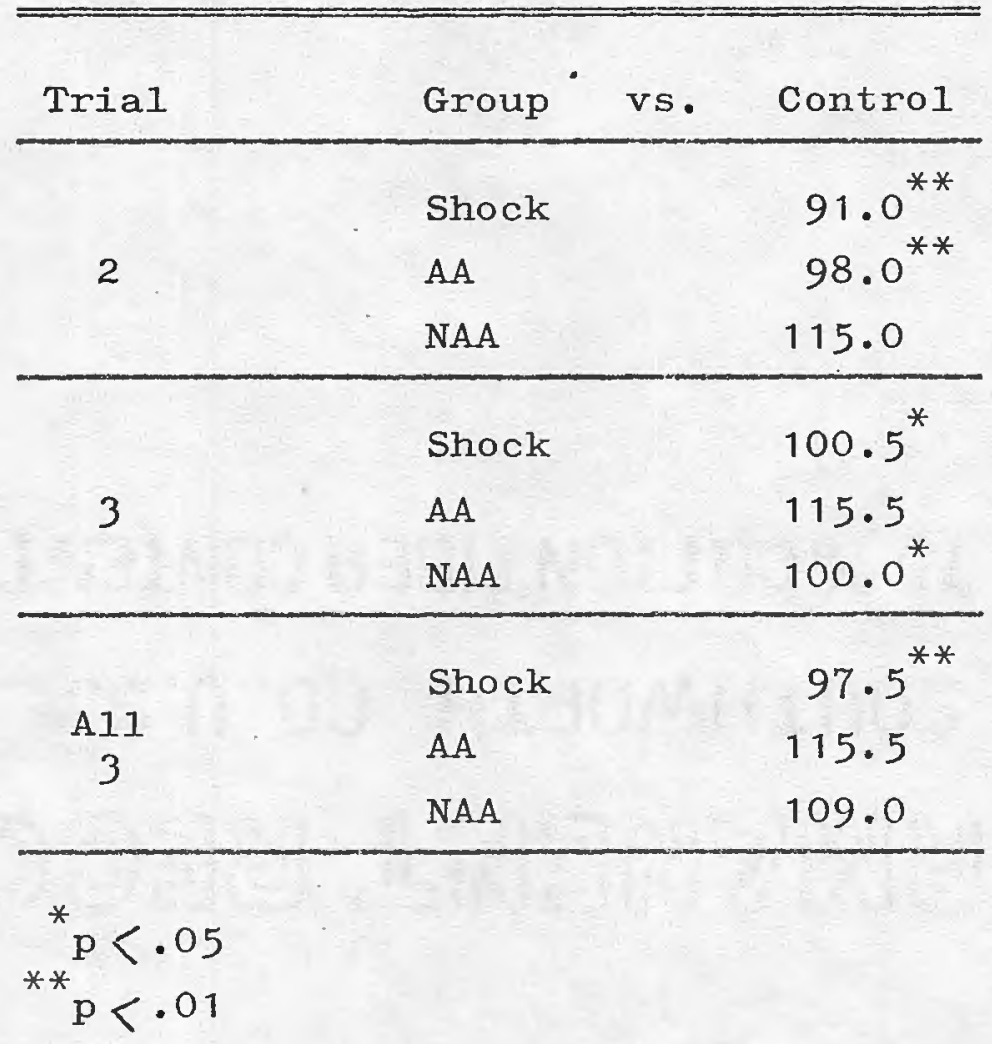


the HC group; although other groups differed from the HC group at various times, no other group displayed this consistent pattern.

Changes in Performances of the Groups--Number of Squares Entered

The data were examined in order to determine whether a group's performance on any one trial differed from its performance on another. If differences were found to exist, inspection of the nature of the differences might reveal meaningful data. For example, if a later performance was better (more squares entered) than an earlier performance(s), it would appear likely that a reduction in emotionality had occurred. One might conclude that there is an adaptation effect occurring and the subjects are profiting from their experiences in a novel situation. If the reverse occurred, it would seem that there had been an increase in anxiety and emotionality.

One-way analyses of variance were performed on the number of squares entered on each trial for each group. That is, each individual group's performances were studied to determine whether there were any differences among their separate performances. The NAA group was the only group in which performance on one trial differed from its performance on another. A Neuman-Keuls Analysis indicated that the only significant differences were between the first and third trials, and that significantly more squares were entered on the third trial. The differences between the 
other trials were not significant. The NAA group, therefore, was the only group that seemed to show a reduction in emotionality over the trials.

\section{Change in Performances of the Groups--Time to Emerge}

The same procedure was carried out to determine whether a group's performance differed on any one trial in regard to time to emerge. Again, if a later performance was better (a reduction in time to emerge) than an earlier performance(s), it would seem likely that a reduction in emotionality had occurred. If there is an increase in the time to emerge, it would be likely that there was an increase in anxiety and emotionality.

The assumption of homogeneity of variance could not be met for the shock and the AA groups. Kruskal-Wallis analyses of variance yielded significant differences among the AA group's performances $(\mathrm{H}=8.181, \mathrm{p}<.02)$, but not for the shock group's performances $(H=2.422, \mathrm{p}>.05)$. MannWhitney U Tests (Siegel, 1956) indicated that the AA group's performances on the first and second trials were significantly different, with the second trial showing a marked reduction in time to emerge. There were no differences between the other trials.

Parametric analyses of variance found no differences to exist among the NAA and HC groups' performances. 
Analysis of Defecation and Urination in the Open-Field

It was hypothesized that those rats that did not receive infantile stimulation would defecate and urinate significantly more in the open-field than those rats that did receive infantile stimulation. Chi-square tests were performed to test whether any differences existed in the number of rats that defecated on each trial in the open-field. Significant differences in the amount of animals that defecated were found only on the first trial. Separate chi-square tests, taking one group at a time versus another group, Yates' correction for continuity applied, indicated that significantly fewer rats defecated in the shock and AA groups than in the HC group.

Chi-square tests showed that there were no differences between the number of rats in each group that urinated in the open-field on the three trials.

Number of Errors in the Hebb-Williams Maze

The total number of errors on the twelve test problems was the score for each subject. The mean number of errors per group are presented in Table 6. Animals stimulated in infancy were expected to make fewer errors than those that were not stimulated. A parametric analysis of variance was performed to determine whether the administration of the experimental treatments had any effect on problem-solving ability in the Hebb-Williams maze. As shown in Appendix A, the analysis of variance indicated 


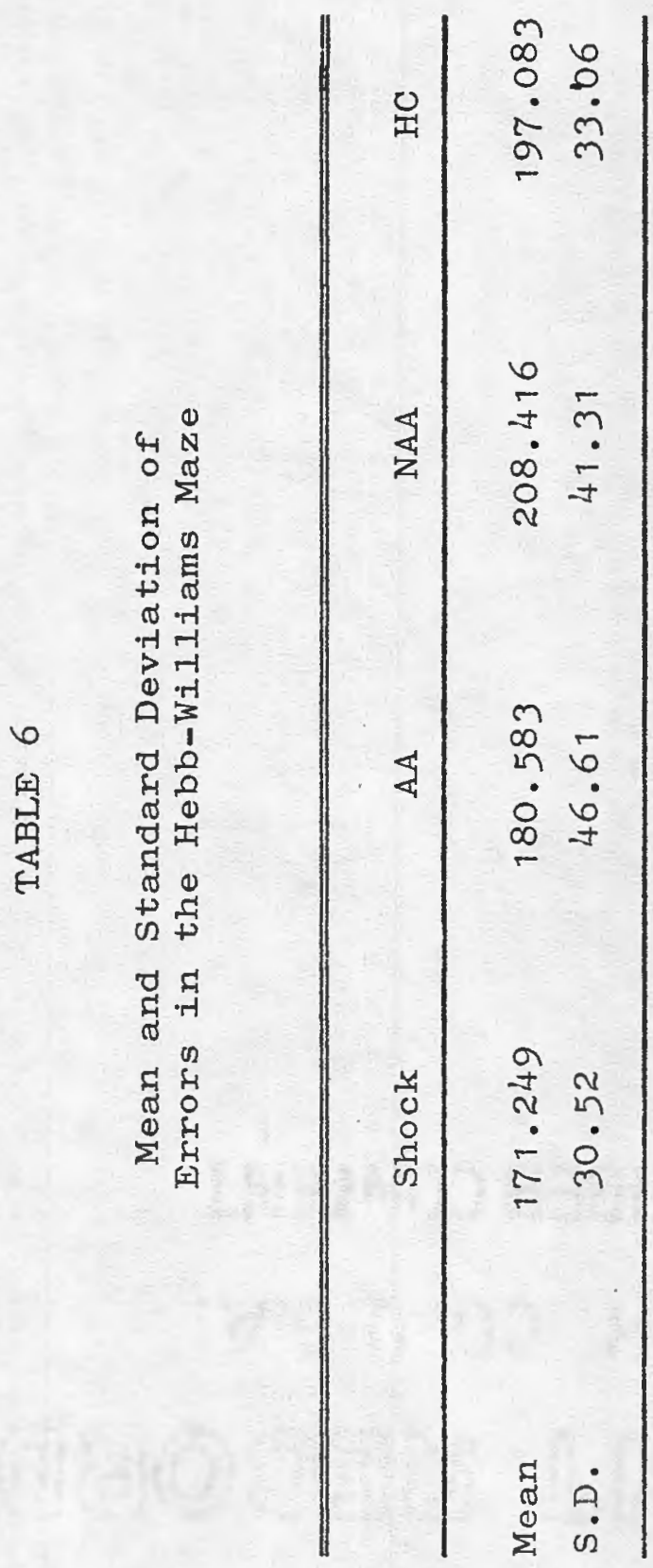


that there were no differences between the groups in problem-solving ability. 


\section{DISCUSSION}

One of the major purposes of this study was to determine whether Helson's or Hebb's hypothesis was more efficient in regard to emotionality and learning. Hebb, it will be recalled, pointed out that regardless of the types of early stimulation, if administered before the development of autonomic processes that are conceived to mediate an organism's capacity to profit from later experience, will all have the same effect (1949). Helson postulated that any stimuli repeatedly encountered loses some of its special characteristics over time and gradually becomes typical. However, important differences exist among the various sense modalities in rates of adaptation (1964), such as between auditory and shock stimulation.

In terms of problem-solving ability, Helson would have predicted that there would be differences between the experimental groups due to the differences that exist among the various sense modalities in rates of adaptation. Not only were there no differences between the experimental groups, but there were also no differences between the experimental groups and the handled control group. Whereas the majority of investigators (Brown, 1966; Denenberg, Woodcock, and Rosenberg, 1968; Forgays and Forgays, 1952; Hebb, 1947) find that animals reared under different con- 
ditions differ in their problem-solving ability, these results are not universal. Denenberg and Morton (1962b) found that the preweaning procedures of handling, larger cages, and greater opportunity for visual experience did not effect problem-solving behavior as measured by the Hebb-Williams maze. Schaefer (1963) found no difference between handled rats and nonmanipulated controls in the Hebb-Williams maze. Of more relevance, Griffiths and Stringer (1952) found no differences in learning ability between rats subjected to an intense auditory stimulus, rats that were shocked, and control (unmolested) rats. In the present study the type of stimulation did not have a differential effect on the problem-solving ability of the rats.

These results fail to support Helson, since he would have predicted a difference to exist at least between the two different sensory modalities. On the other hand, one cannot determine if they support or contradict Hebb due to the loss of the nonhandled control group. It is true that the experimental groups did not differ from each other, but they would all have to differ from the nonhandled control group in the same fashion for his theory to be correct. In regard to the variable of emotionality, the results are mixed and do not lead to any clear-cut conclusions. The number of squares entered in the open-field differed on the third trial only. There were no differences between the experimental groups, but the shock and 
NAA group differed from the handled control. Time to emerge from the start box into the open-field was significant on trials two and three but not on the first. However, the differences that existed in every case were not between the experimental groups. Although the experimental groups did not differ from each other in their performance on these two measures, some of the experimental groups' performances did differ from the handled control group's performance. When differences existed, the shock group was always the group or one of the groups that differed from the control condition. In other words, the findings showed that although there were no differences in the effects of equally aversive auditory and tactile stimulation, and also no difference between the above and the effects of nonaversive auditory stimulation, differences existed between some of these groups and the handled control group. In every instance, the handled control group was the most emotional.

Helson would have predicted that the performance of the groups would differ, especially when the auditory and shock groups were compared. This did not occur and support for Helson is lacking. However, one cannot infer that Hebb's theory is correct. To be completely correct, not only would there be no differences between the experimental. groups, but the experimental groups would all differ consistently and in the same direction from the nonhandled 
control group. Again, due to the loss of the nonhandled control group, one is limited in the conclusions that can be drawn.

A puzzling finding was the fact that the number of squares entered in the open-field differed on only the third trial, and differences in the time to emerge from the start box into the open-field occurred on the second and third trials. It was expected that if differences existed, it would most likely occur on the first trial. An interesting finding related to the above was that the NAA group's performance between the first and third trials was significantly different in regard to the number of squares entered in the open-field, which argues for a reduction in emotionality between those trials. The performances of the shock, AA, and control groups on any one trial did not differ from their performance on the other trials. This finding suggests that the NAA group was profiting from its initial experience in a novel situation. Possibly, this is related to the fact that the stimulation received in infancy was not aversive.

A similar pattern occurred in regard to the NAA group's time to emerge from the start box. Whereas the means for all other groups increased, the mean for the NAA group decreased. Also, it should be noted that the handled control group always did better (though not significantly better) on the second trial in regard to the number of 
squares entered and time to emerge, but its performance always deteriorated (not significant1y) on the third trial. The other groups did not show a consistent pattern.

These findings lead one to wonder what results one would obtain if more trials were included over a period of time; it appears that the NAA group is profiting from its experiences in a novel situation. It is conceivable that these rats, although initially anxious in novel situations, adapt to the situation, become less anxious, and perform better. Whether this finding is a result of the stimulation being nonaversive cannot be determined on the basis of this study.

The data also stand in partial contradiction to Levine (1959), and Salama and Hunt's (1964) notion that it is stimulation per se that matters in regard to emotionality. If this were the case, one would expect that all the groups that received any form of stimulation would not differ from each other, but would all differ in the same fashion from the nonhandled control group. The absence of the nonhandled control group makes this postulation impossible to test. However, shock stimulation appeared to be the most efficacious mode of early experience or stimulation when compared to the handled control group. Furthermore, some of the other groups at various times differed from the handled control. On the basis of these findings, it appears that all the forms of stimulation utilized in 
this study are not equal in their effects, and that handling alone was the least effective. Although there were no significant differences between the shock and the other experimental groups, in most instances, the shock group did have the best performance.

The mixed results within this study seem to reflect the inconsistencies between the studies that are reported in the literature. The inconsistencies between studies on problem-solving ability have been cited above. Some investigators do not find a reduction of emotionality as a consequence of early stimulation (Griffiths and Stringer, 1952), and some find results to the contrary (Hall and Whiteman, 1951).

While the effects of infantile stimulation on aduit emotionality are not consistent, its effects on childhood emotionality are more striking. The most significant finding of this study only related indirectly to the work of Helson (1959), Hebb (1949), Levine (1959), and Freud (1905), in the sense that their concern was with the ef.fects of early experience on adult functioning vis-a-vis learning and emotionality. Specifically, Freud postulated that the experience of traumatic stimulation in infancy rendered an individual more prone to anxiety in adulthood. Hebb, Helson, Levine, and others have shown that stimulation in infancy has the salutary effect of reducing emotionality and increasing learning ability in adulthood. 
An unexpected result of the present study was that the number of rats that died before reaching adulthood was not normally distributed throughout the groups. Including the period of weaning, the number that died in the NAA and NHC groups was significantly different from each other, as was the case with the HC and NHC groups. The shock and NHC groups, and the AA and NHC groups approached, but did not reach significance. In all instances, the NHC group had the highest mortality rate.

Whereas the aforementioned investigators studied the effects of early experience (and the effects of not receiving early experience) in adulthood, the findings of the present study suggest that within the developmental period of childhood, the effects of receiving or not receiving stimulation may have important consequences.

The procedure entailed at least two anxiety-provoking situations for the rats before they reached adult status. All rats were left unmolested in their litters until the eleventh day of life. To administer the experimental treatments, it was necessary that the pups be removed one at a time from the litter. This can be construed as an anxiety-provoking situation, since the litter was unexpectedly disturbed and the pups taken away from the mother for a period of time. Secondly, weaning is also an extremely stressful situation. It should be noted that since some were dying within the first eighteen hours after 
weaning occurred, the rats were returned to the mothers and weaned at 30 days of age. The second set of subjects were not attempted to be weaned at 21 days of age, but at 30 days instead.

Since the nonstimulated animals had the highest mortality rate, one beneficial effect of infantile stimulation seemed to be, therefore, to imbue those animals with a greater capacity to survive the, stress of being suddenly taken away from their mother.

It should be noted that this author could not find one study in the literature that reported a high mortality rate for a nonstimulated group. In fact, no study reports that any animals died, no matter which group they belonged to. Two explanations are possible: (1) those that died were replaced, and (2) none died. If the first explanation is correct, then valuable data and information may be lost by not studying which animals died.

Studies of early infantile experience have reached almost voluminous proportions. However, almost all deal with the effects of early experience in adulthood. Spitz (1946) and Ribble (1943) are among the few (in comparison to those that study the effects of infantile stimulation in adulthood) that show the deleterious and irreversible effects of emotional and stimulus deprivation in the infant. Animal analogue studies of this type of research, in which the effects of early stimulation are studied before adulthood, are virtually nonexistent. 


\section{APPENDIX A}

Chi-square Values of the Comparison of Number of Rats That Died in Each Group

\begin{tabular}{lcccc} 
& S-AA & NAA & HC & NHC \\
\hline S-AA & -1859 & .5456 & 3.4158 \\
NAA & - & .9758 & $3.9898 *$ \\
HC & & & & $4.9664^{*}$ \\
NHC & & & - \\
\hline
\end{tabular}

* $p<.05$ 


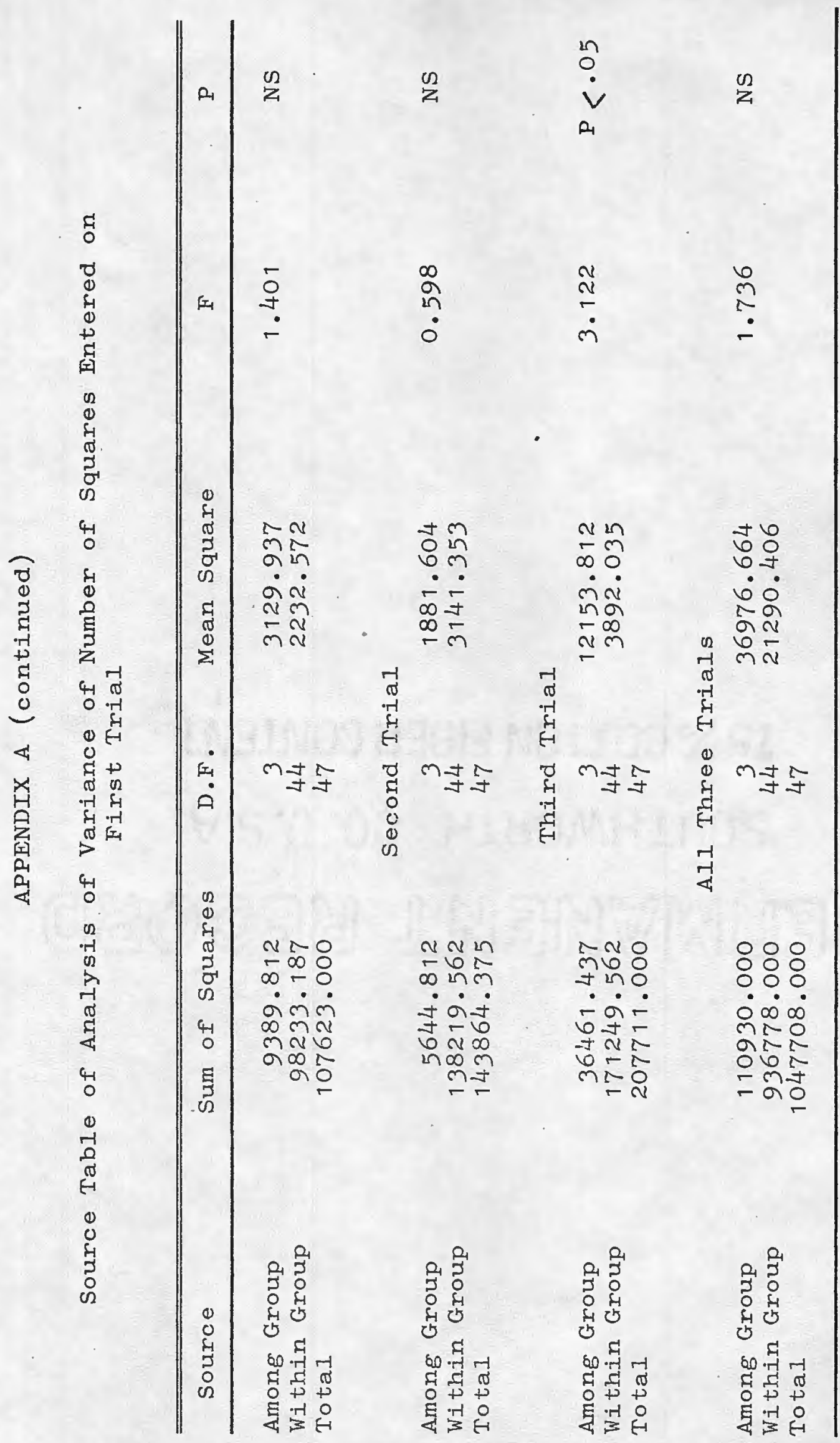




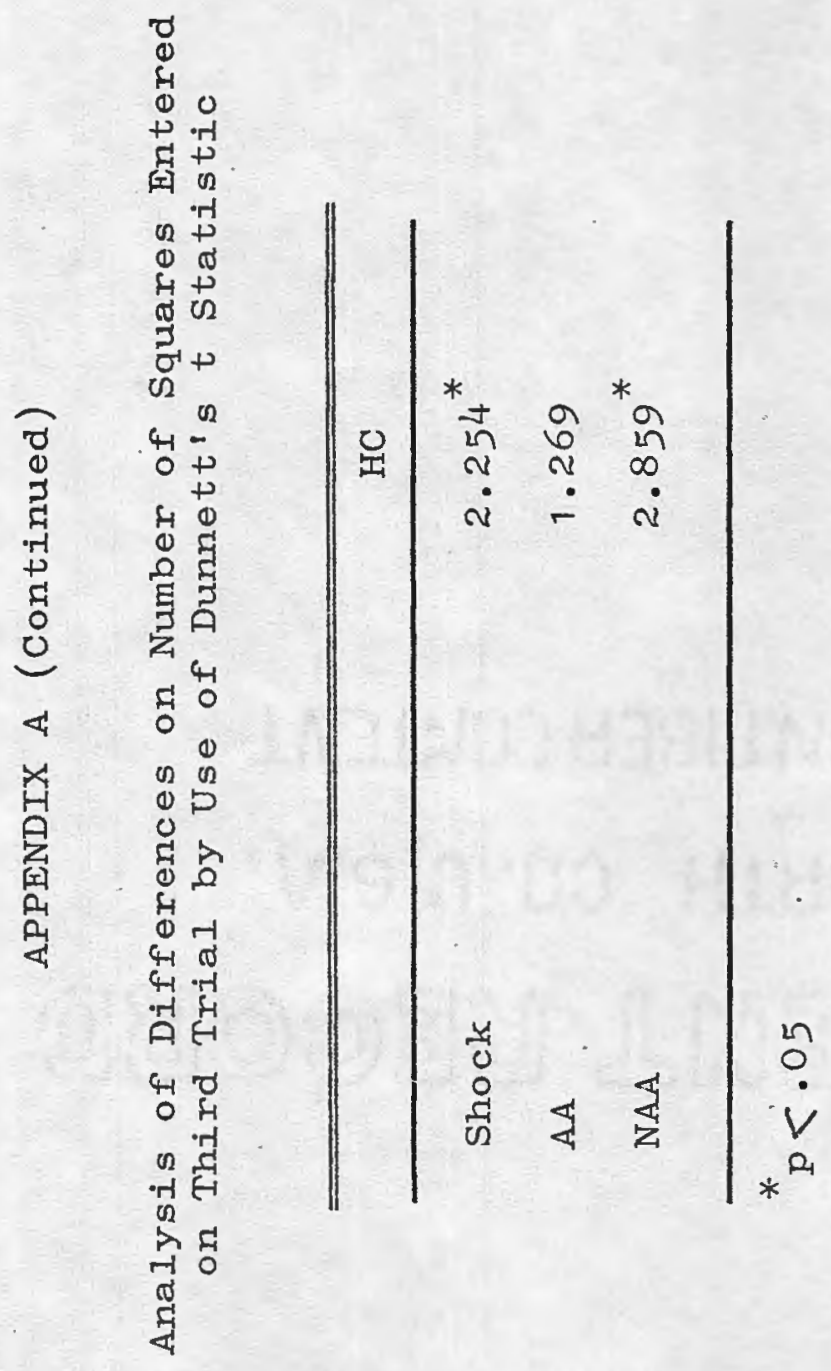




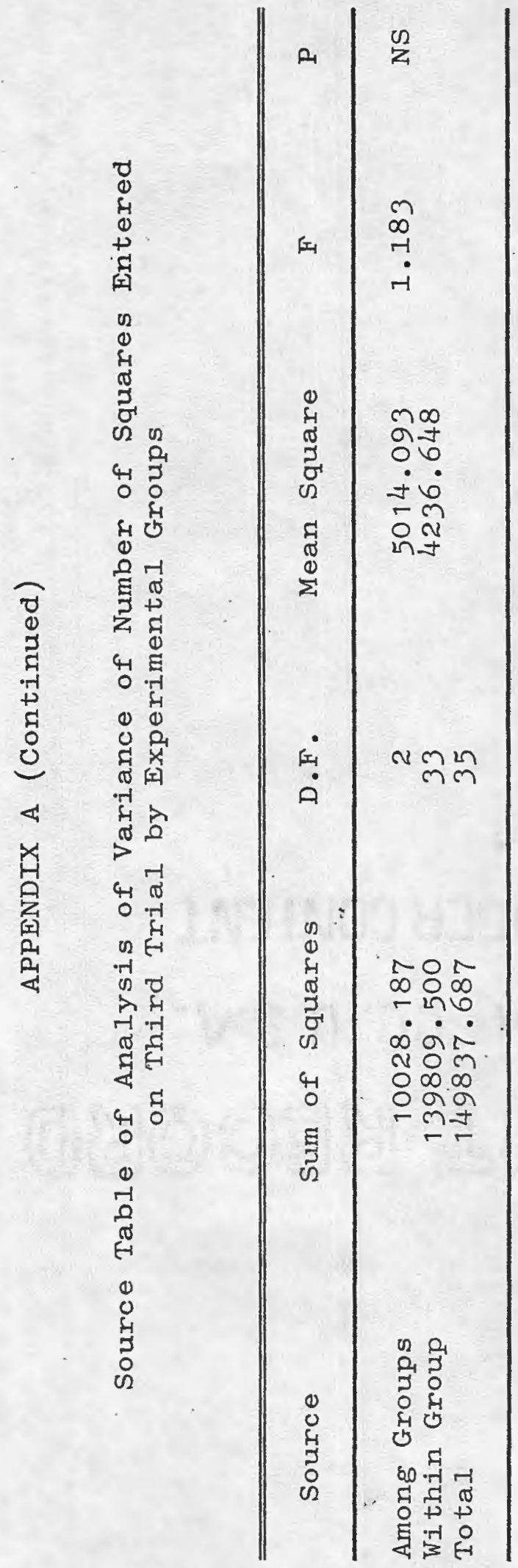




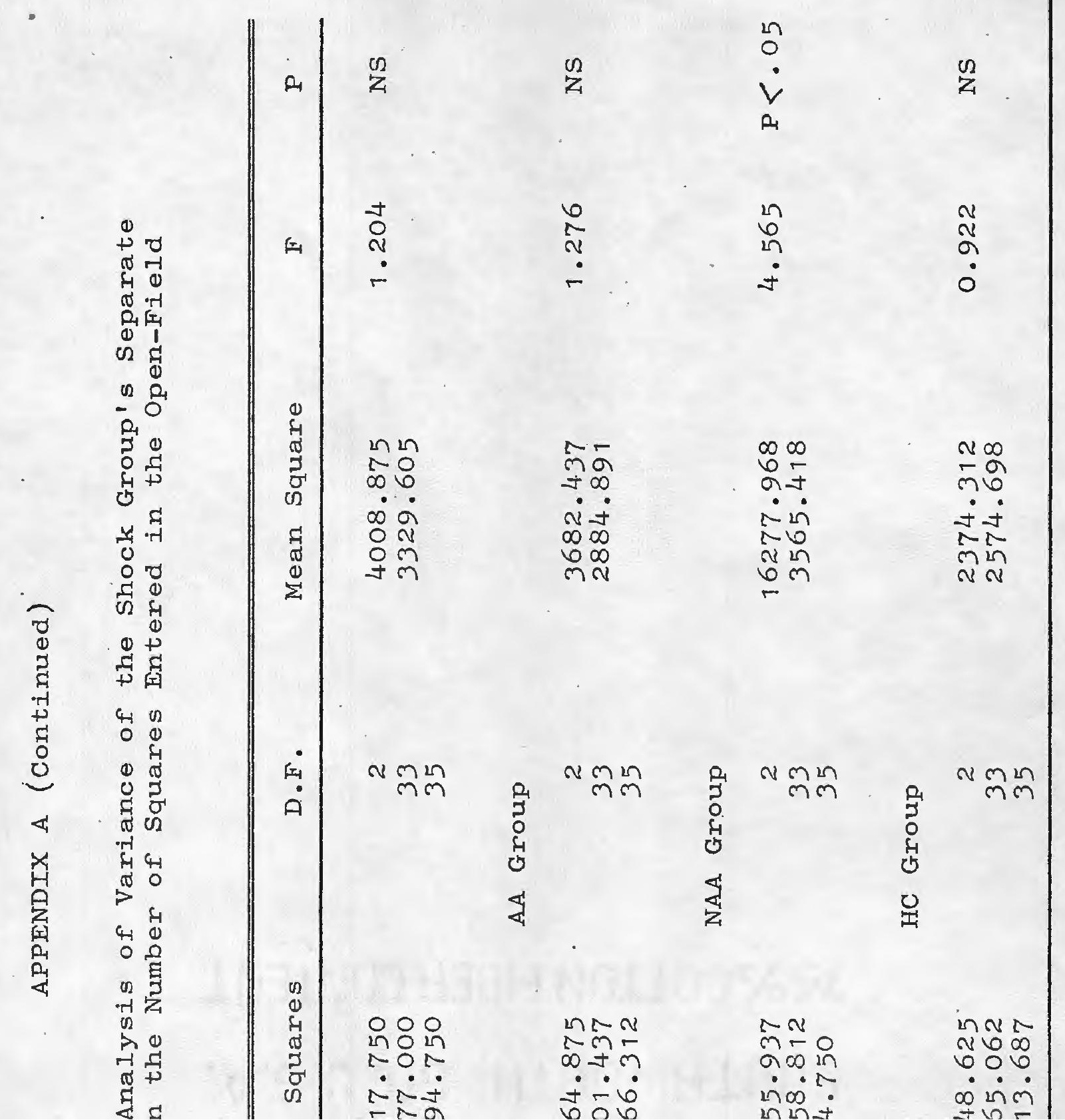




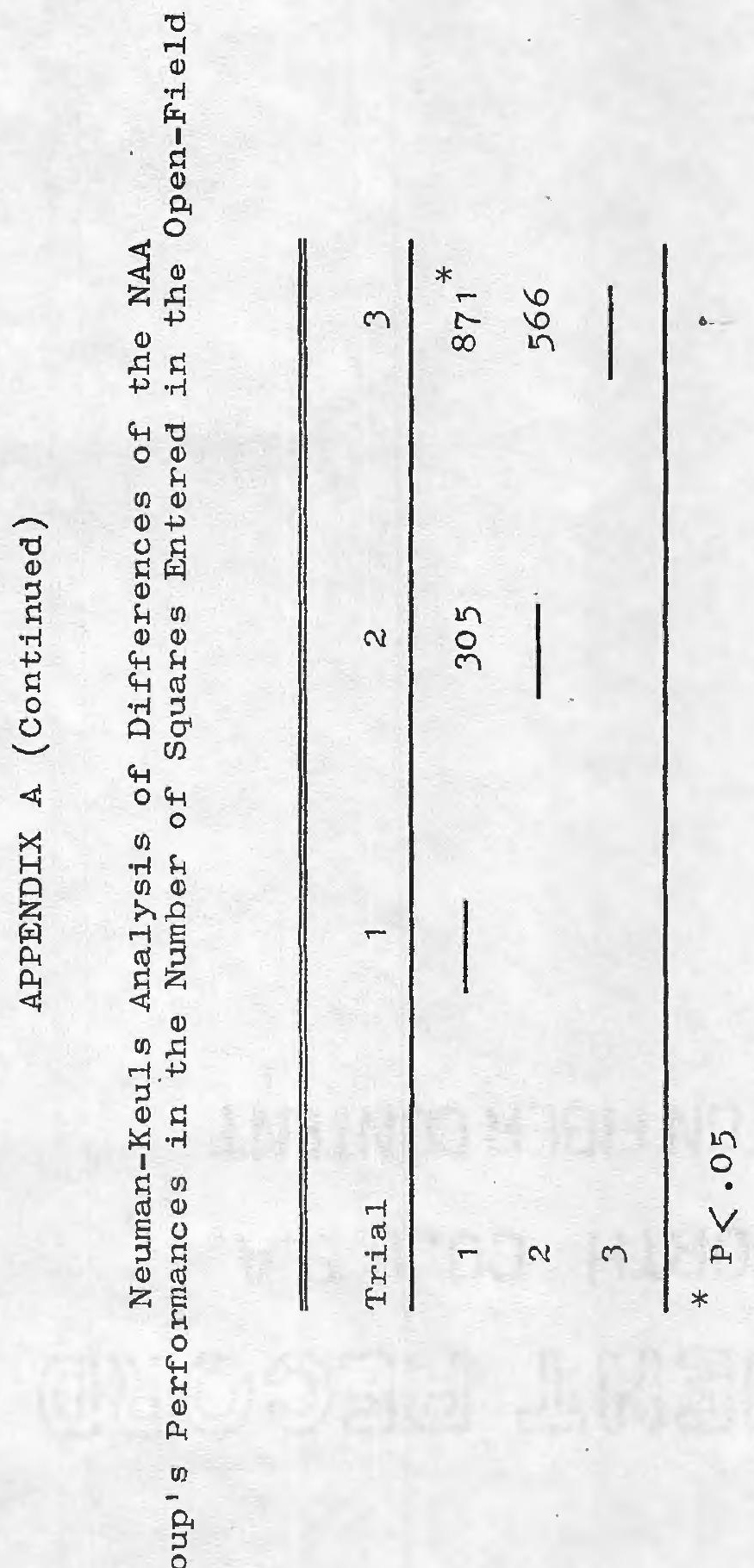




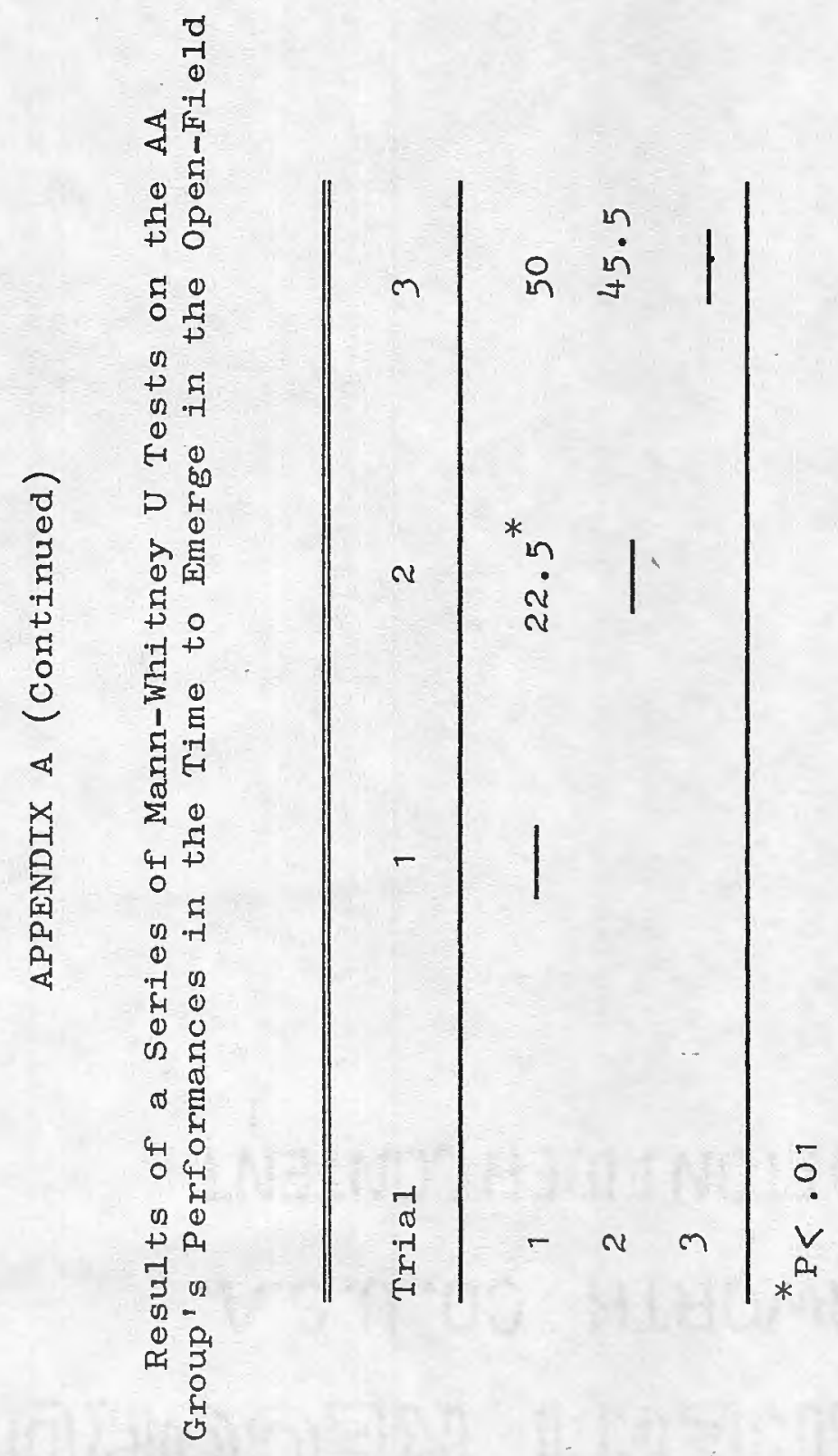




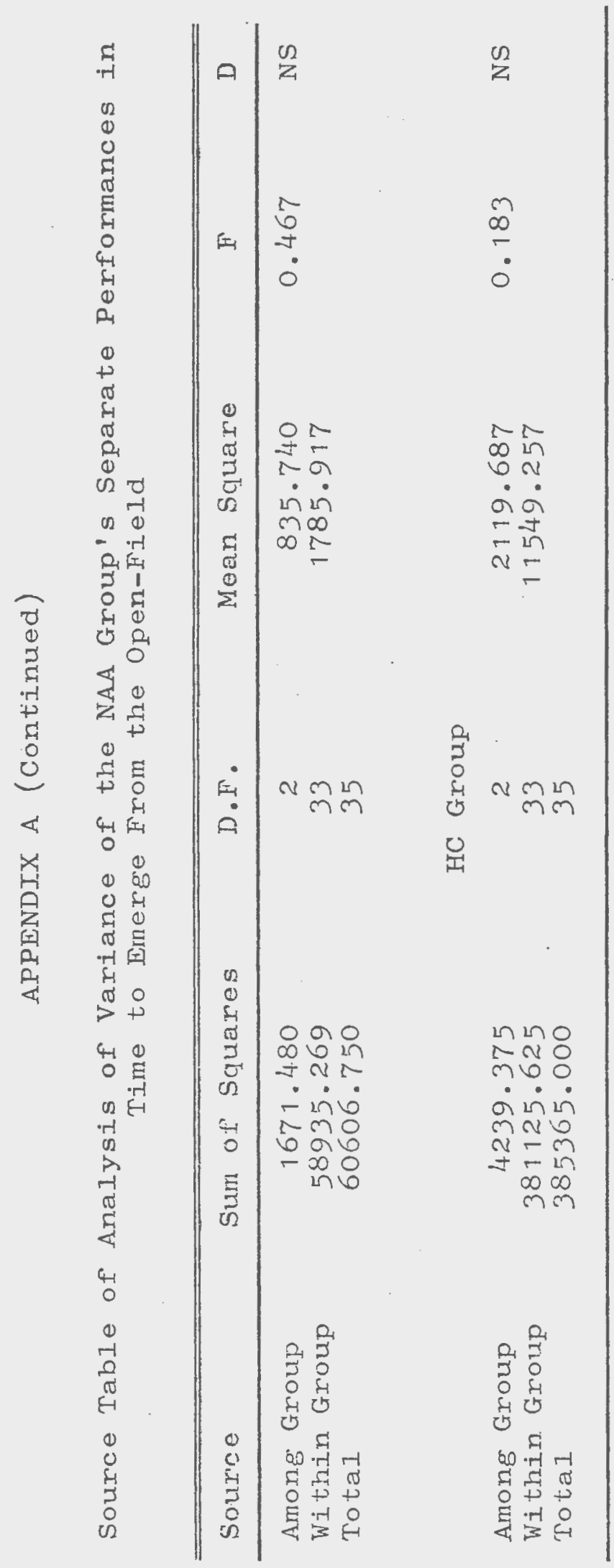




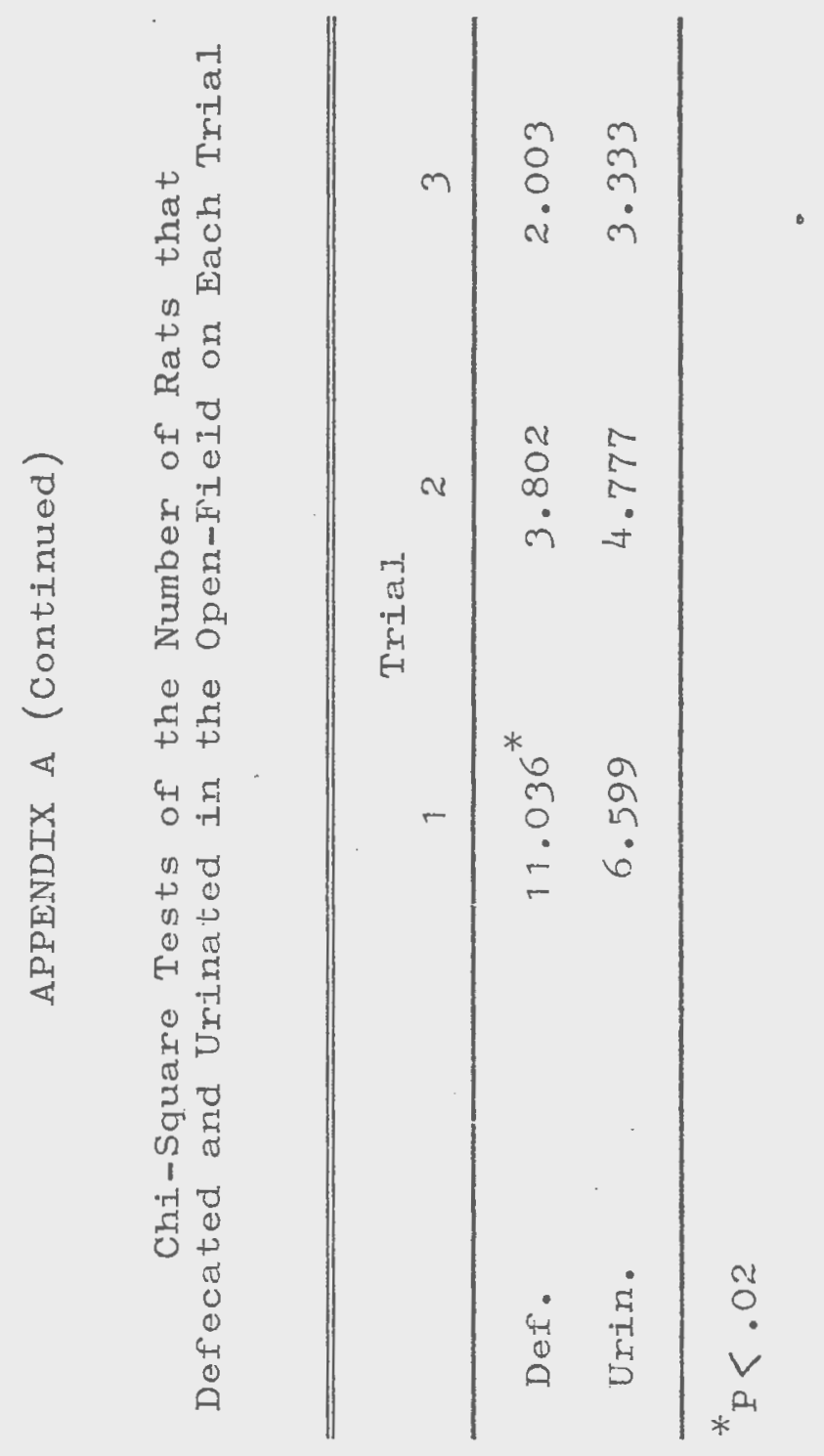




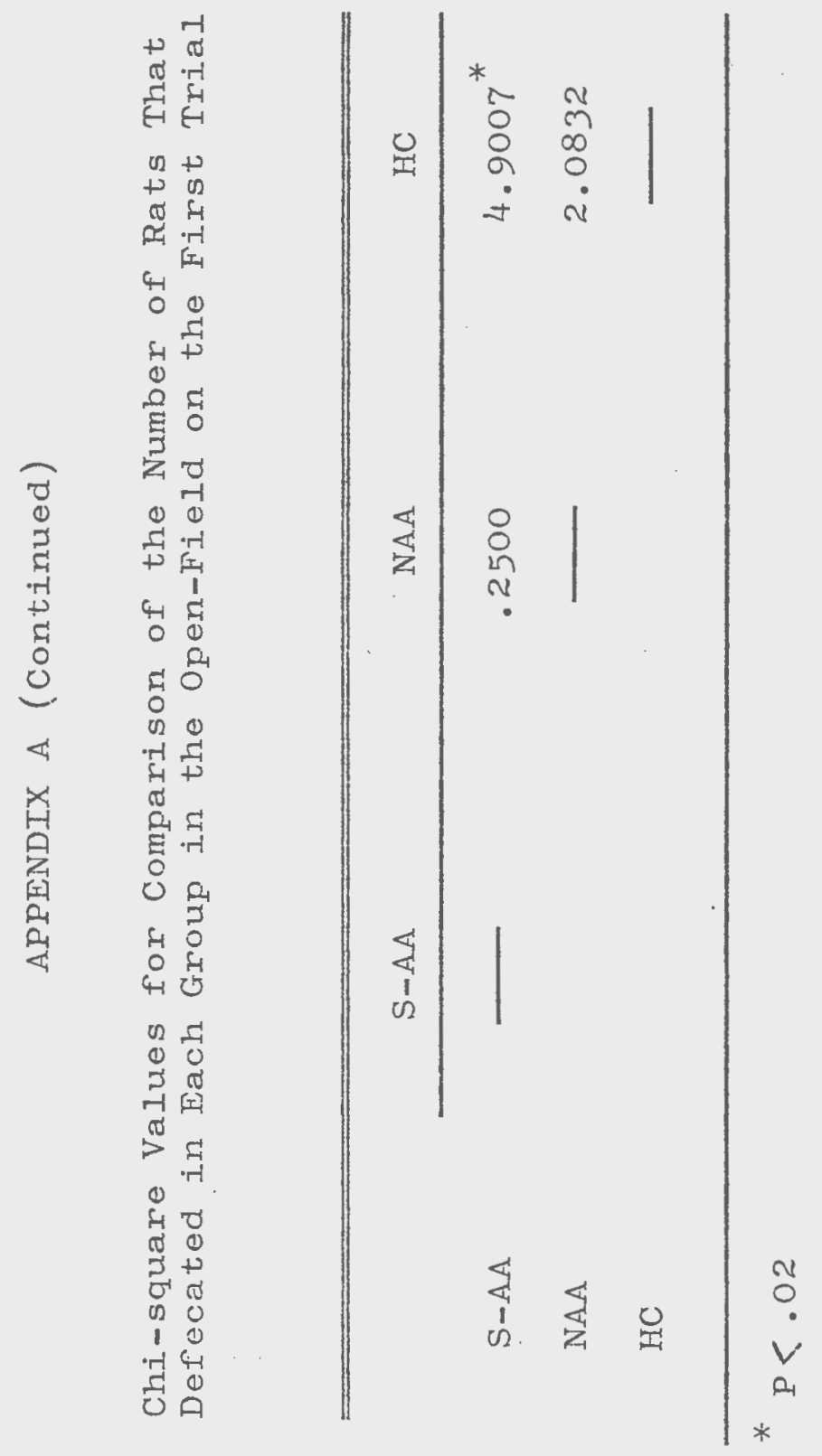




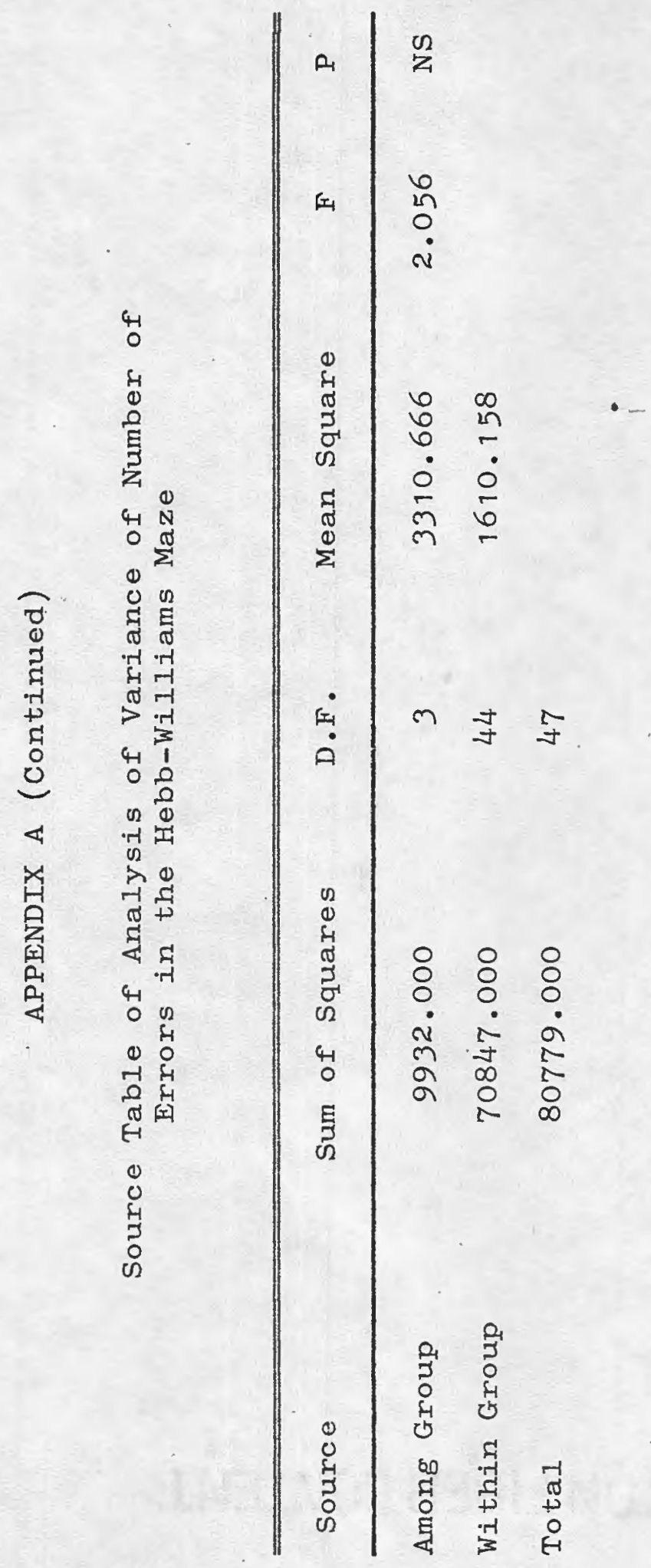




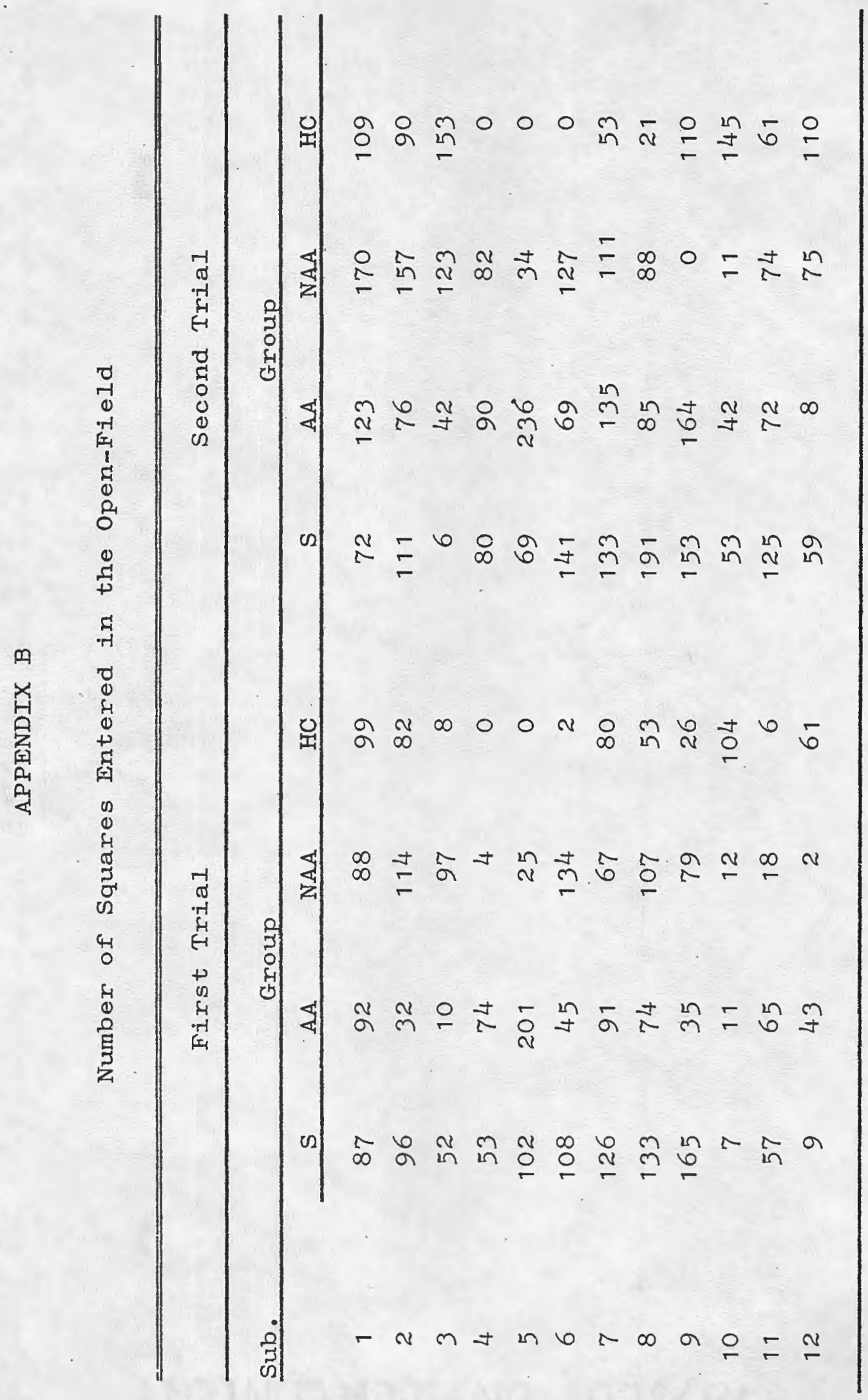




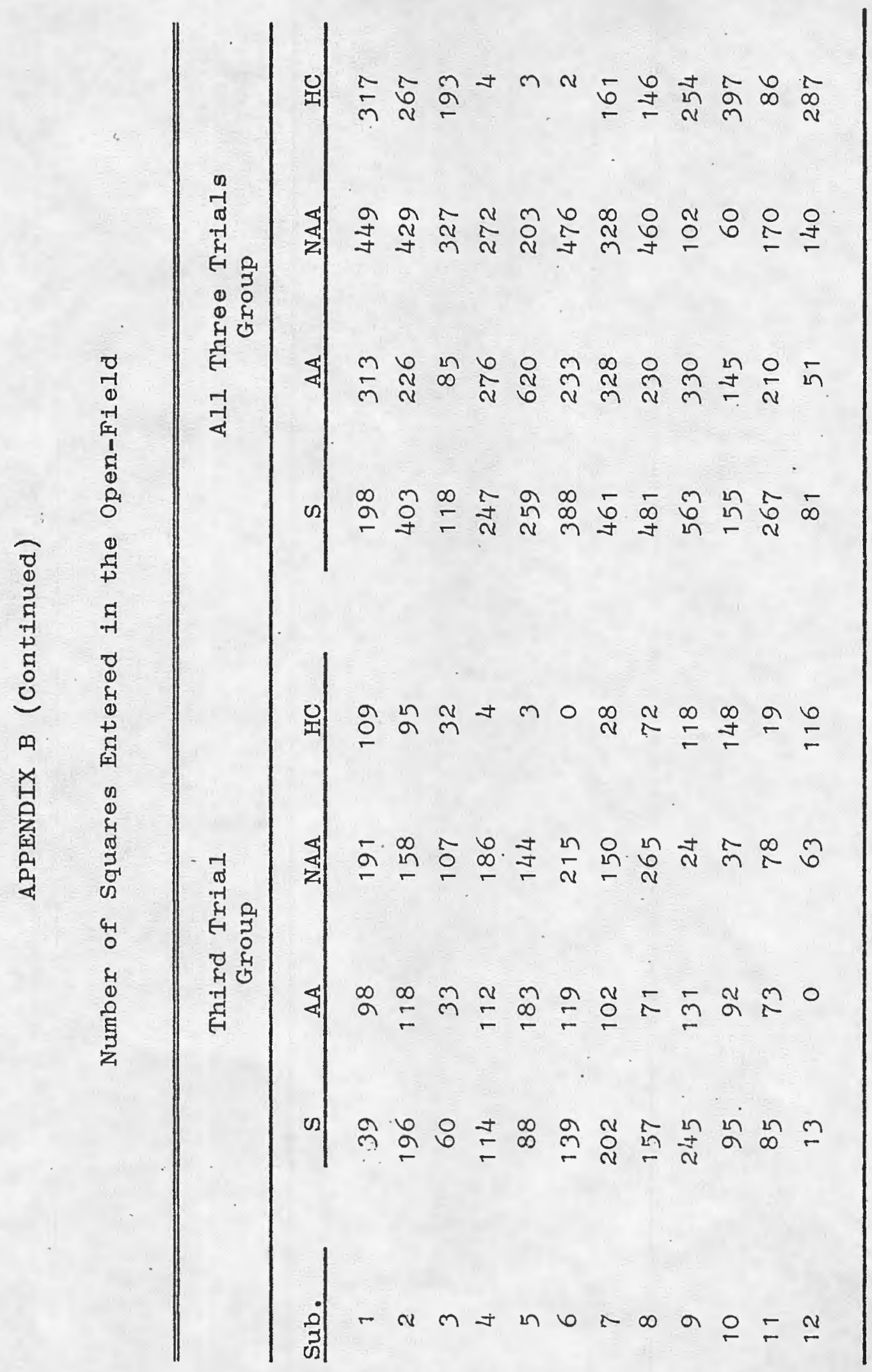




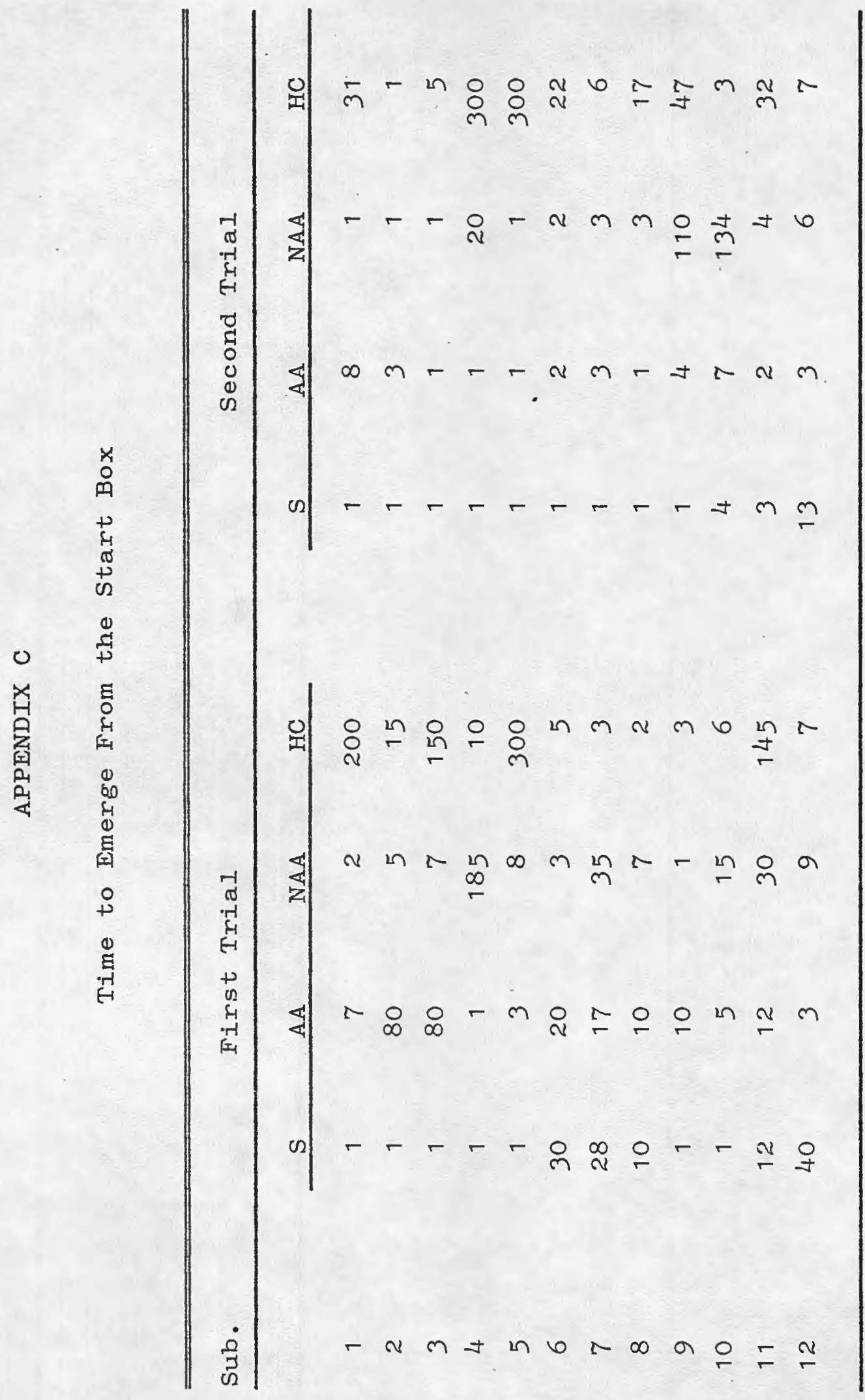




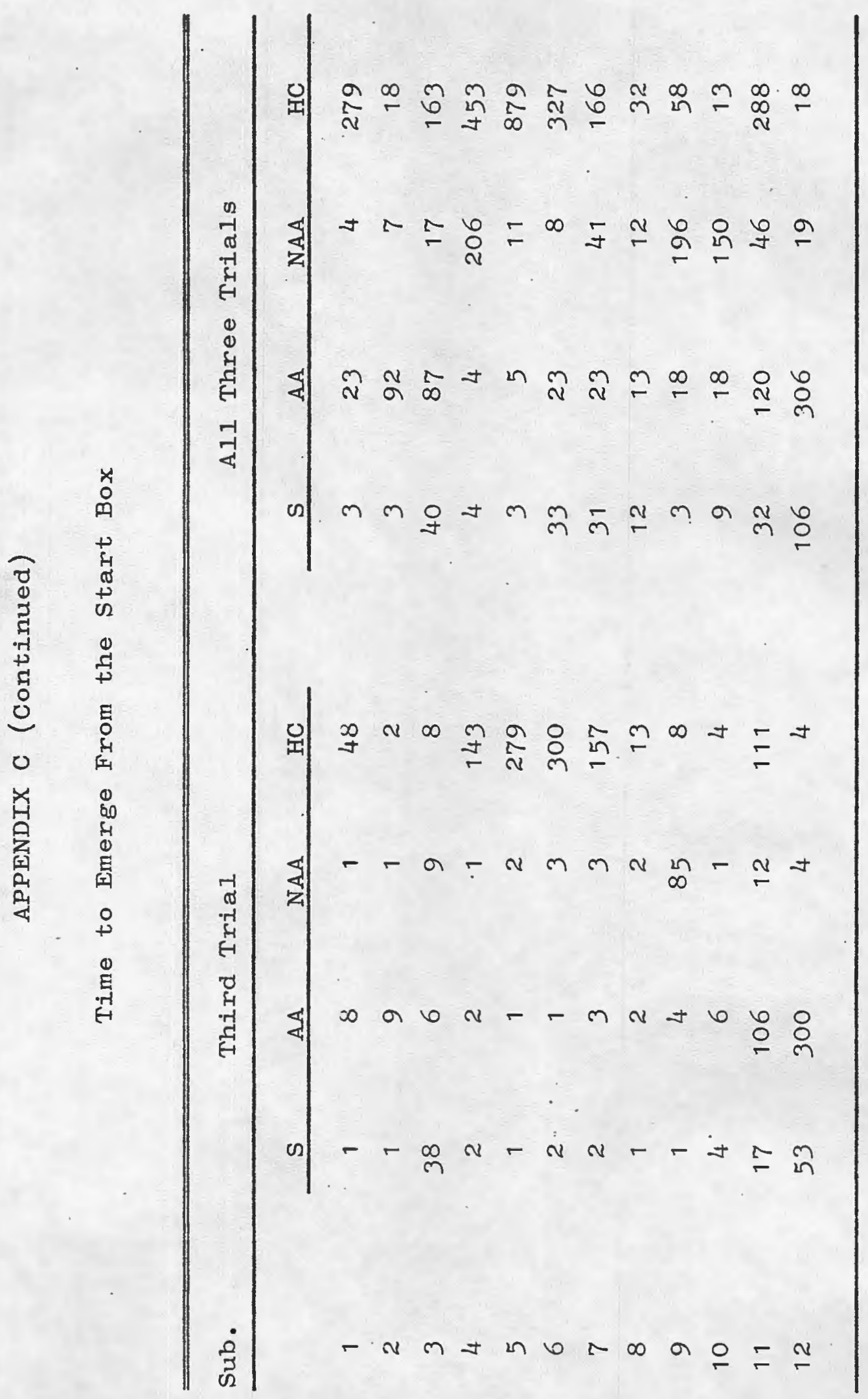




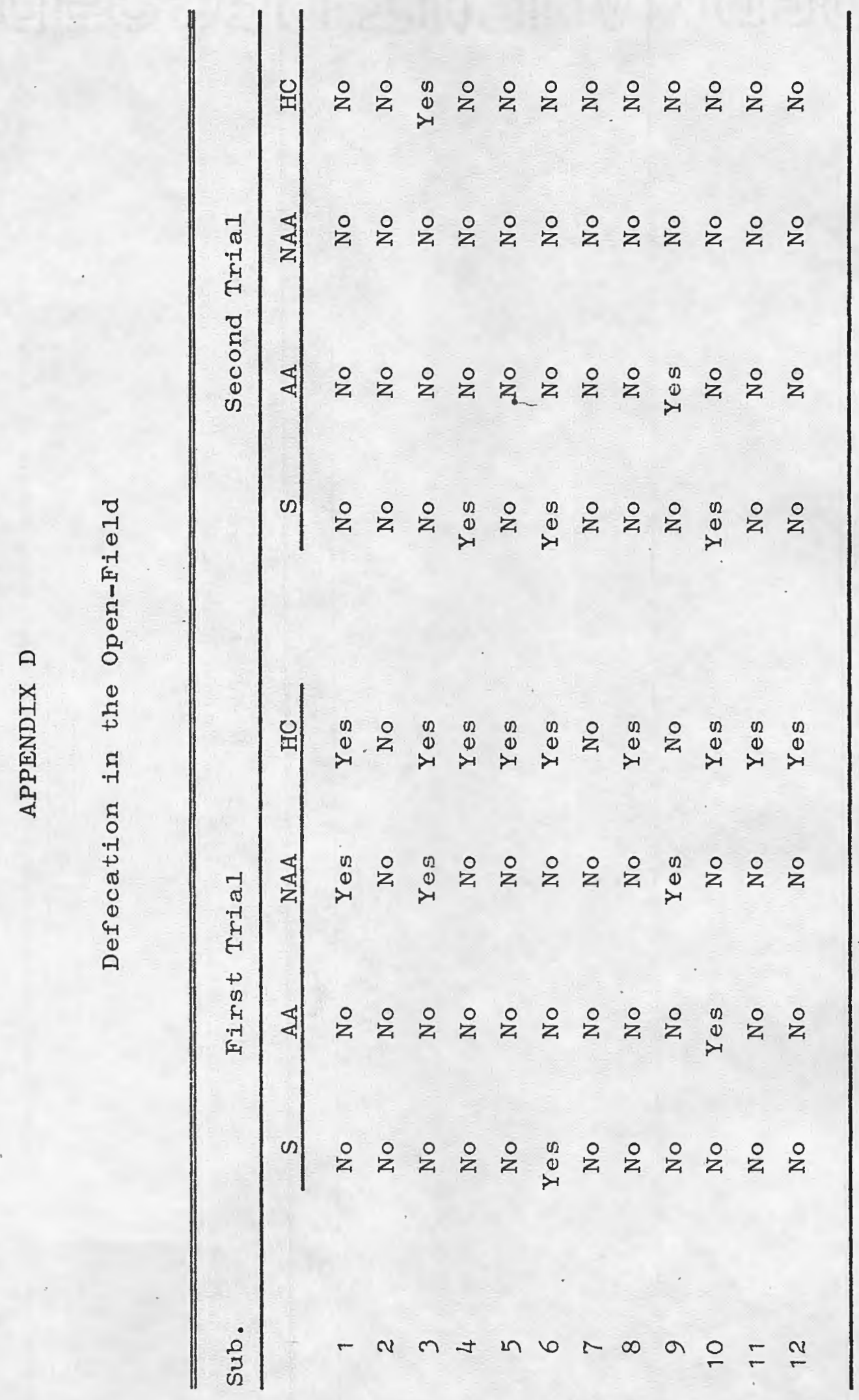




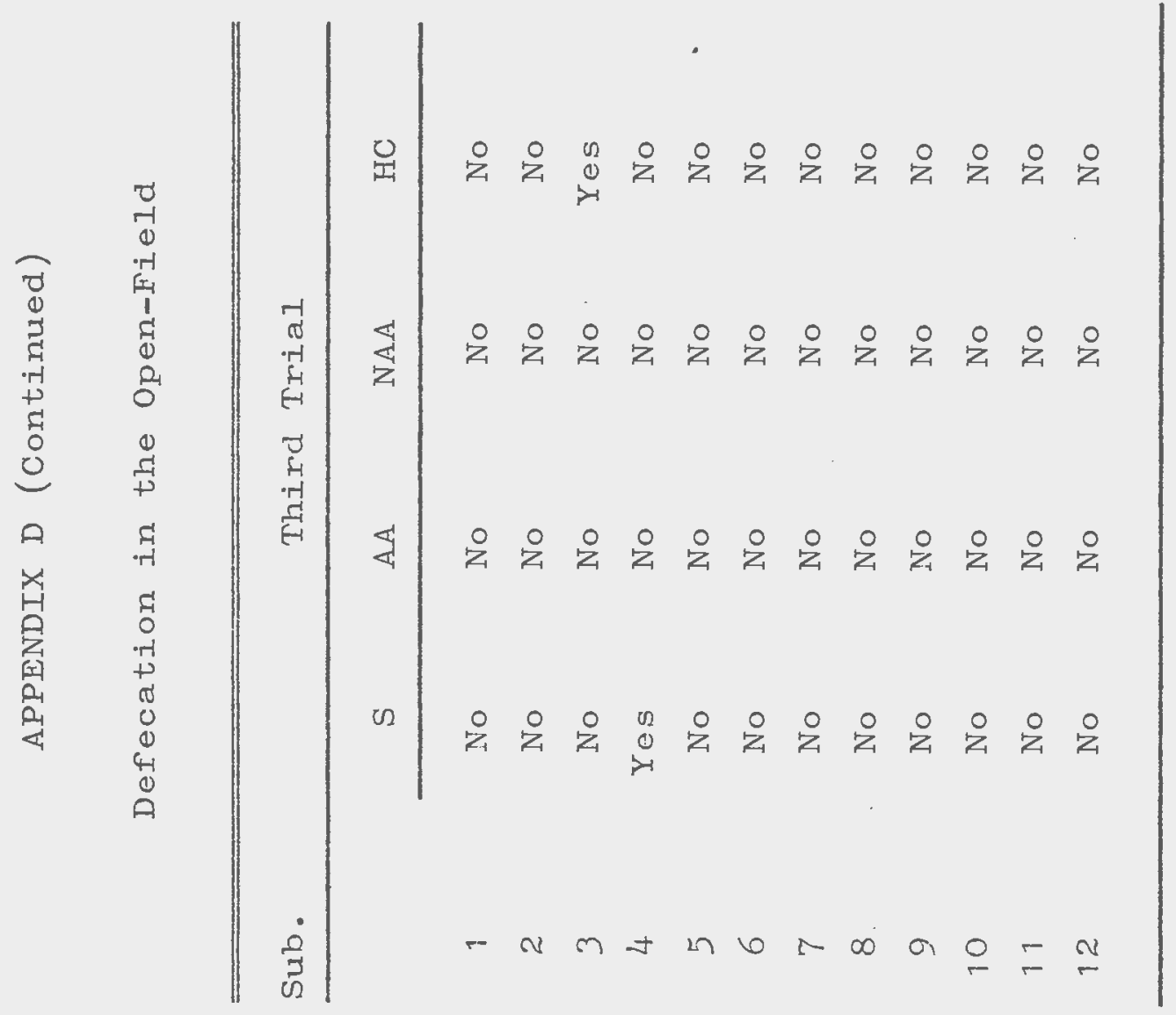




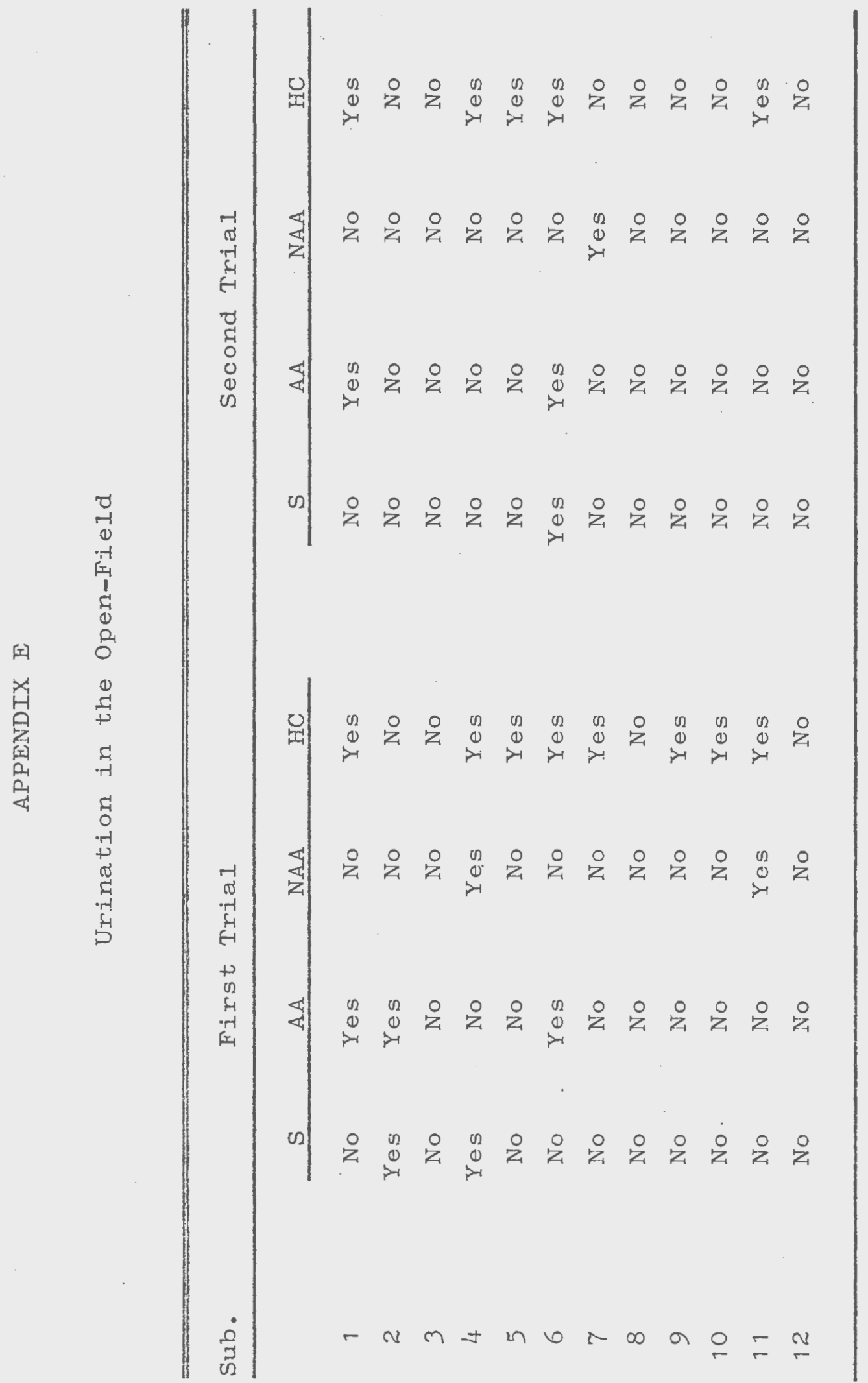




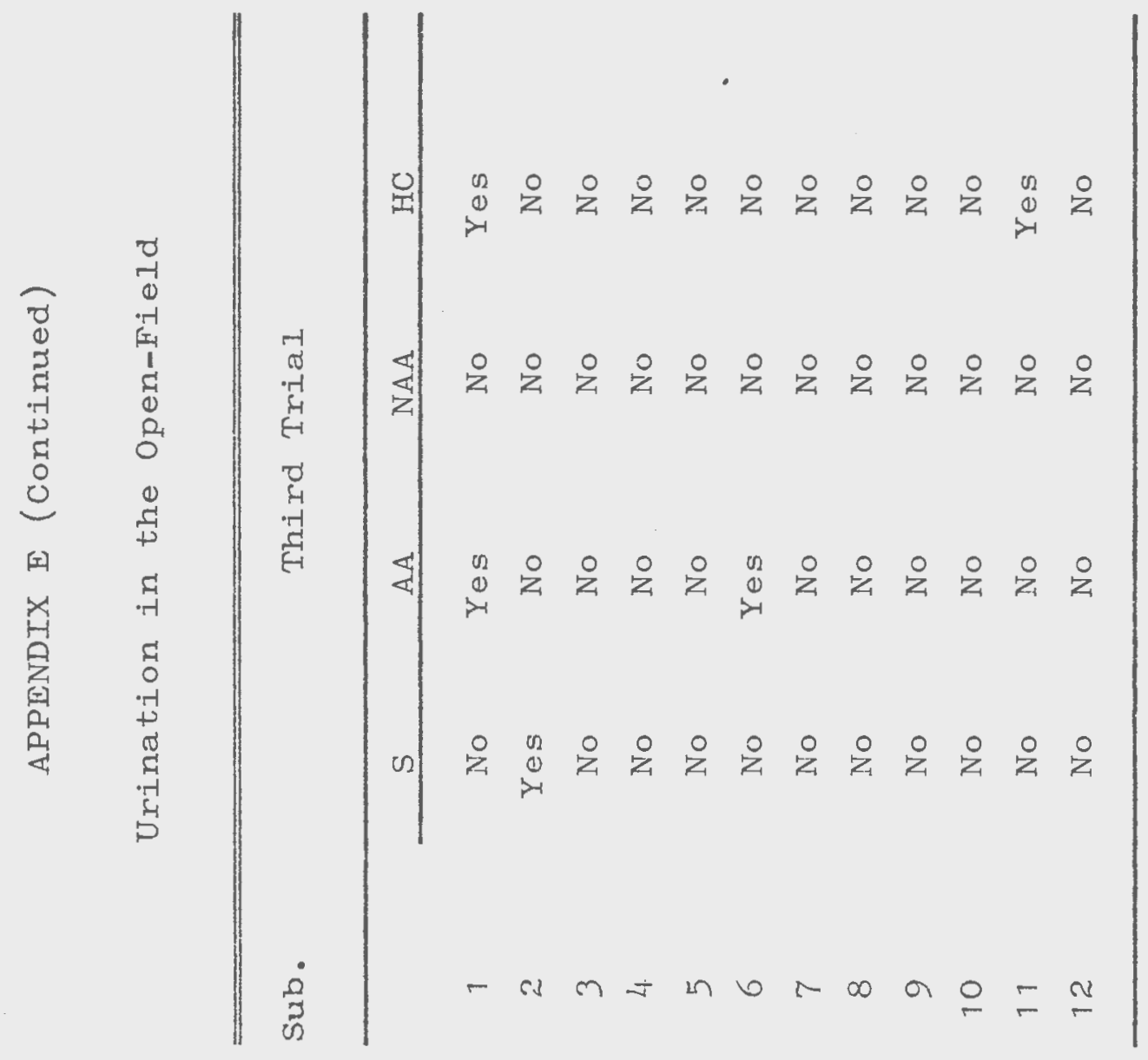




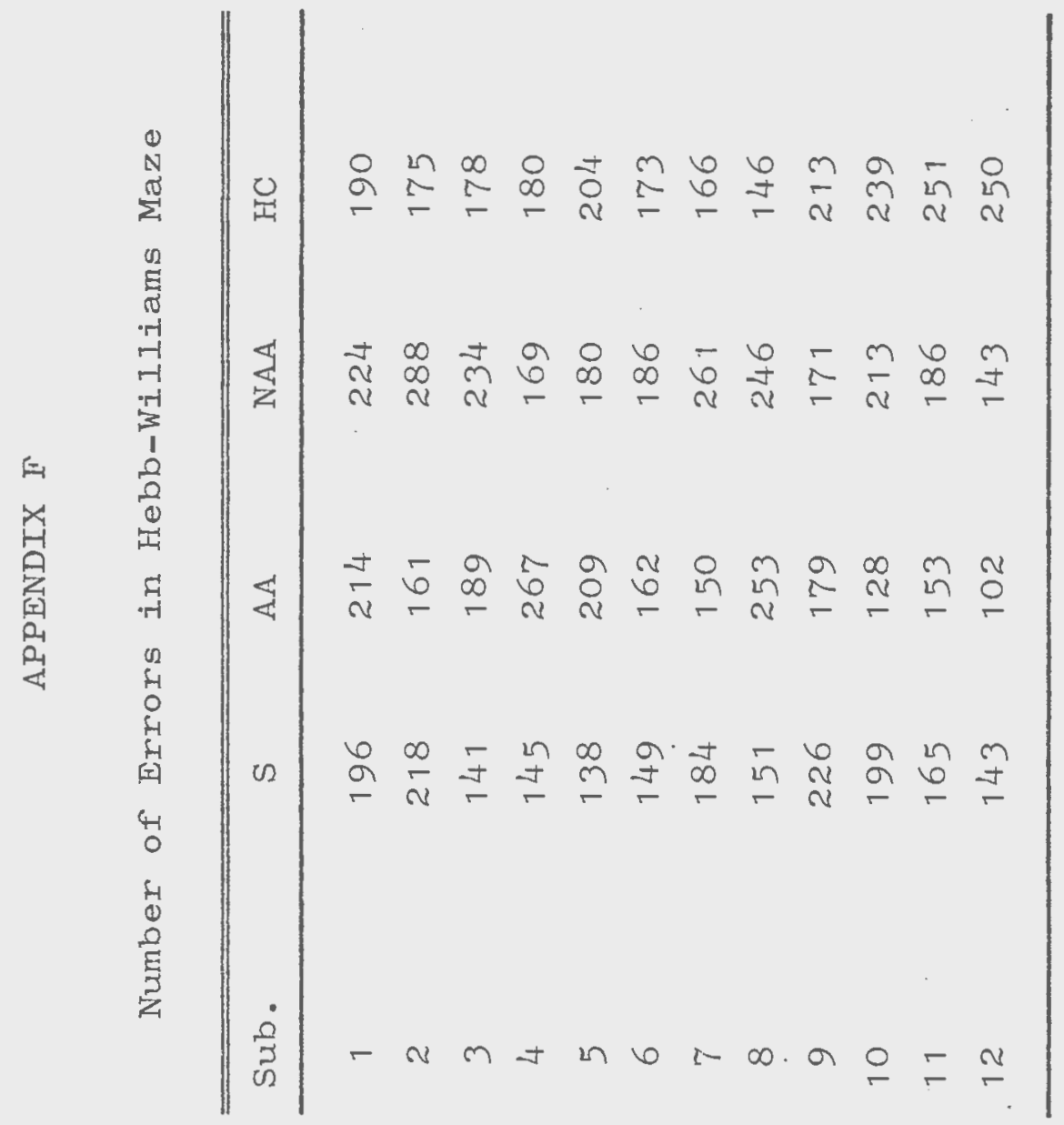


REFERENCES

Ader, R. Effects of early experience on emotional and physiological reactivity in the rat. Journal of Comparative and Physiological Psychology, 1968, 66, 264-268.

Brown, R. T. Early experience and problem-solving ability. Journal of Comparative and, Physiological Psychology, $1968,65,433-440$.

Campbe11, B. A. Auditory and aversion thresholds of rats for bands of noise. Science, 1957, 125, 596-597.

Campbe11, B. A., \& Bloom, J. M. Relative aversiveness of noise and shock. Journal of Comparative and Physiological Psychology, 1965, 60, 440-442.

Campbell, B. A., \& Teghtsoonian, R. Electrical and behavioral effects of different types of shock stimuli on the rat. Journal of Comparative and Physiological Psychology, 1958, 51, 185-192.

Denenberg, V. H. Critical periods, stimulus input, and emotional reactivity: A theory of infantile stimulation. Psychological Review, 1964, Z1, 335-351.

Denenberg, V. H., \& Morton, J. R. C. Effects of environmental complexity and social groupings upon modification of emotional behavior. Journal of Comparative and Physiological Psychology, $1962,55, \overline{24} \overline{2-246 .(\mathrm{a})}$

Denenberg, V. H., \& Morton, J. R. C. Effects of preweaning and postweaning manipulations upon problen-solving behavior. Journal of Comparative and Physiological. Psychology, 1962, $55, \frac{1096-1098 .}{(\mathrm{b})}$

Denenberg, V. H., \& Smith, S. A. Effects of infantile stimulation and age upon behavior. Joumal of Comparative and Physiological Psychology, 1968, 66, $533-535$.

Downie, N. M., \& Heath, R. W. Basic statistical methods. New York: Harper and Row, 1964. 
Forgays, D. G., \& Forgays, J. W. The nature of the effect of free-environmental experience in the rat. Journal of Comparative and Physiological Psychology, 1952, 45, $322-328$.

Freud, S. The psychopathology of everyday life. In A. Brill (Trans. \& Ed.), The basic writings of Sigmund Freud. New York: Modern Library, 1938. Pp. 35-178. Three contributions to the theory of sex, originally published 1905).

Griffiths, W. J., \& Stringer, W. F. The effects of intense stimulation experienced during infancy on adult behavior in the rat. Journal of Comparative and Physiological Psychology, 1952, 45, 301-306.

Hall, C. S., \& Whiteman, P. H. The effects of infantile stimulation upon later emotional stability in the mouse. Journal of Comparative and Physiological Psychology, 1951, 44, 61-66.

Hebb, D. O. The effects of early experience on problemsolving at maturity. American Psychologist, 1947, 2. $306-307$.

Hebb, D. O. The organization of behavior. New York: Wiley, 1949 .

Helson, H. Adaptation-level theory. In S. Koch (Ed.), Psychology: A study of science. Vol. 1. Sensory, perceptual, and physiological formulations. New York: McGraw-Hi11, 1959 .

Helson, H. Adaptation-level theory. New York: Harper and Row, 1964.

Hunt, J. The psychological basis for using pre-school enrichment as an antidote for cultural. deprivation. Merril-Palmer Quarterly, 1964, 10, 209-248.

Hunt, H. F., \& Otis, L. S. Early "experience" and its effects on later behavioral processes in rats: I. initial experiments. Transactions of the New York Acaderny of Science, $1963,25,858-870$.

King, J. A. Parameters relevant to determining the effect of early experience upon the adult behavior of animals. Psychological Bulletin, 1958, 55, 46-58.

Levine, S. Infantile experience and consummatory behavior in adulthood. Journal of Comparative and Physiological Psychology, 1957, 50, 609-612. 
Levine, S. Noxious stimulation in infant and adult rats and consummatory behavior. Journal of Comparative and Physiological Psychology, 1958, $\frac{51}{230-233 .}$

Levine, S. The effects of differential infantile stimulation on emotionality at weaning. Canadian Journal of Psychology, 1959, 13, 243-247.

Lindholm, B. W. Critical periods and the effects of early shock on later emotional behavior in the white rat. Journal of Comparative and Physiological. Psychology, $1962,55,597-599$.

Masterson, F. A. Equal aversion functions as predictors of instrumental responding. (Doctoral dissertation, Princeton University) Ann Arbor, Mich .: University Microfilms, 1966. No. 66-7174.

Rabinovitch, M. S., \& Rosvold, H. E. A closed-field intelligence test for rats. Canadian Journal of Psychology, $1951,2,122-128$.

Ribble, Margaret. The rights of infants. New York: Columbia University Press, 1943.

Salama, A., \& Hunt, J. "Fixation" in the rat as a function of infantile shocking, handling and gentling. Journal of Genetic Psychology, 1964, 105, 131-162.

Schaefer, T. Early "Experience" and its effects on later behavioral processes in rats: II. A critical factor in the early handling phenomenon. Transactions of the New York Academy of Science, 1963, 25, 871-889.

Siegel, S. Nonparametric statistics for the behavioral scjences. New York: NcGraw-Hili, 1956.

Spence, J. T., \& Naher, B. A. Handling and noxious stimulation of the albino rat: $I$. effects on subsequent emotionality. Journal of Comparative and Physiologica1 Psvchology, 1962, 55, $247-251$. (a)

Spence, J. T., \& Maher, B. A. Handling and noxious stimulation of the albino rat: II. effects on subsequent performance in a learning situation. Journal of Comparative and Physiological Psychology, 1962, 55 , $252-255 \cdot(\mathrm{b})$

Spitz, R. A. Anaclitic depression. In The psychoanalytic study of the child. Vol. 2. New York: International Universities Press, 19:6. 
Steel, R. G. D. A multiple comparison rank sum test: Treatments versus control. Biometrics, 1959, 15, 560-572.

Winer, B. J. Statistical principles in experimental design. New York: McGraw-Hil1, 1962.

Wong, R. Infantile handling and performance in the $T$-maze. Psychonomic Science, 1966, 2, 203-204.

Woods, P. J., Fiske, A. S., \& Ruckelshaus, S. I. The effects of drives conflicting with exploration on the problem-solving behavior of rats reared in free and restricted environments. Journal of Comparative and Physiological Psychology, 1961, 54, 167-169.

Woods, P. J., Ruckelshaus, S. I., \& Bowling, D. M. Some effects of "free" and "restricted" environmental rearing conditions upon adult behavior in the rat. Psychological Reports, 1960 , 6, 191-200. 